\title{
Study of the early hydration of calcium aluminates in the presence of different metallic salts
}

\author{
A. Duran ${ }^{\mathrm{a}}$, R. Sirera ${ }^{\mathrm{a}}$, M. Pérez-Nicolás ${ }^{\mathrm{a}}$, I. Navarro-Blasco ${ }^{\mathrm{a}}$, J.M. Fernández ${ }^{\mathrm{a}}$, J.I. Alvarez ${ }^{\mathrm{a}^{*}}$
}

${ }^{a}$ MIMED Research Group; Department of Chemistry and Soil Sciences, School of Sciences, University of Navarra. Irunlarrea, 1. 31008 Pamplona, Spain

doi:10.1016/j.cemconres.2015.11.013 Available online 19 December 2015

\begin{abstract}
The effect of chlorides and nitrates of $\mathrm{Li}(\mathrm{I}), \mathrm{Cr}(\mathrm{III}), \mathrm{Zn}(\mathrm{II}), \mathrm{Cu}(\mathrm{II}), \mathrm{Pb}(\mathrm{II})$ nitrate and $\mathrm{Cr}(\mathrm{VI})$ (chromate) on the early hydration of ternary system of calcium aluminates (CA, $\left.\mathrm{CA}_{2}, \mathrm{C}_{12} \mathrm{~A}_{7}\right)$ was reported. $\mathrm{Li}(\mathrm{I})$ and $\mathrm{Cr}(\mathrm{III})$ caused a strong acceleration of the hydration, while $\mathrm{Zn}(\mathrm{II})$ as well as chromate gave rise to a slight acceleration. On the contrary, $\mathrm{Pb}$ (II) and $\mathrm{Cu}(\mathrm{II})$ retarded the hydration. A clear formation of AFm phases during the first hydration stages was found and related to the acceleration ability. Anions (nitrate or chloride as counterions or even chromate) were able to be incorporated into the interlayer space of AFm, yielding insoluble and stable compounds. A balance between the insolubility of the metal hydroxides (dependant on the low amphoteric character of the compound) and the ability of the formation of AFm hydrates seems to be very important to lean the equilibrium towards the retarding of the hydration or towards the acceleration, respectively.
\end{abstract}




\section{Introduction}

The use of calcium aluminate cements as an efficient binding system to confine hazardous materials has shown a growing interest [1-3]. Several advantages have been reported, such as rapid increment of mechanical strength and high resistance to aggressive agents. Literature provides different phases that appear in calcium aluminate cements following hydration processes, including metastable compounds such as $\mathrm{CaAl}_{2} \mathrm{O}_{4} \cdot 10 \mathrm{H}_{2} \mathrm{O}\left(\mathrm{CAH}_{10}\right), \mathrm{Ca}_{2} \mathrm{Al}_{2} \mathrm{O}_{5} \cdot 8 \mathrm{H}_{2} \mathrm{O}\left(\mathrm{C}_{2} \mathrm{AH}_{8}\right), \mathrm{Ca}_{4} \mathrm{Al}_{2} \mathrm{O}_{7} \cdot \mathrm{xH}_{2} \mathrm{O}(\mathrm{x}=7,11,13$ and 19), and also stable hydrates such as $\mathrm{Ca}_{3} \mathrm{Al}_{2} \mathrm{O}_{6} \cdot 6 \mathrm{H}_{2} \mathrm{O}\left(\mathrm{C}_{3} \mathrm{AH}_{6}\right)$ and $\mathrm{Al}_{2} \mathrm{O}_{3} \cdot 3 \mathrm{H}_{2} \mathrm{O}\left(\mathrm{AH}_{3}\right)$, depending on temperature of the process, curing time, mineralogical composition of the raw cement material and water/cement ratio [4-5]. However, similarly to Portland cement systems, some metals can have a strong influence on the hydration of anhydrous calcium aluminate phases, resulting in a change of the strength development at very early ages [6]. The performance in the presence of metallic salts is of the utmost importance for solidification/stabilization of hazardous wastes containing such metal cations [7]. Although different mechanisms to explain the action of salts as setting regulators on calcium aluminate hydration have been proposed [8-11], only a few papers dealing with the influence of metal salts on hydration kinetics of anhydrous calcium aluminate phases have been published and the results are sometimes controversial. Analyzing the role that some metal cations might play in calcium aluminate hydration processes would be useful to understand some properties such as hardening, setting time or mechanical strength, all of them relevant properties to ascertain the feasibility of the use of CAC for retaining toxic metals [11]. Since both the cation as well as the anion of the salt may be active agents having influence on the cement hydration, the role of anionic counterions (mainly nitrates and chlorides) has to be also considered. Although diverse mineralogical phases are present in CAC 
commercial binders, monocalcium aluminate (CA) is the predominant hydraulic component, whereas phases as $\mathrm{C}_{12} \mathrm{~A}_{7}, \mathrm{CA}_{2}$ and $\mathrm{C}_{3} \mathrm{~A}$, among others, are present in a minor amount. Given that the interaction between metals and the different phases present in a high alumina cement could be different, the current work focuses on the behaviour of calcium aluminate as obtained by solid-state reaction from a $\mathrm{CaO}: \mathrm{Al}_{2} \mathrm{O}_{3}$ 1:1 mixture, which yielded CA (calcium monoaluminate) as the main phase that grew with $\mathrm{CA}_{2}$ and $\mathrm{C}_{12} \mathrm{~A}_{7}$ as minor components [12-13]. The aim of this work is thus to gain understanding about the effect of metallic salts on the evolution of the phases of these anhydrous calcium aluminates during the early stages of their hydration. The effect of the addition of $1 \%$ wt. $\mathrm{Li}(\mathrm{I}), \mathrm{Cr}(\mathrm{III}), \mathrm{Cu}(\mathrm{II}), \mathrm{Zn}(\mathrm{II})$ chlorides and nitrates, $\mathrm{Pb}(\mathrm{II})$ nitrate as well as $\mathrm{Cr}(\mathrm{VI})$ as potassium chromate at early ages up to 48 hours will be assessed. New insights into the interaction of these metal salts with calcium aluminates are reported.

\section{Materials and methods}

\subsection{Materials}

Calcium aluminium oxide, as calcium monoaluminate, $99 \%$ (metals basis) - 200 Mesh powder $\left(\mathrm{CaAl}_{2} \mathrm{O}_{4}\right)$ (chemical composition $\mathrm{CaO}: \mathrm{Al}_{2} \mathrm{O}_{3}$ 1:1 molar ratio, 35.44 wt.\% $\mathrm{CaO}$ and 64.56 wt.\% $\mathrm{Al}_{2} \mathrm{O}_{3}$ ), provided by Alfa Aesar (A John Matthey Company), was employed as the targeted binder. It is well-known that the obtaining of this phase is usually accompanied by the formation of minor amounts of other phases belonging to different stoichiometries $[12,14]$. XRD examination of the commercial sample, depicted in Fig. 1, showed the presence of CA (ICDD 01-70-0134), as main compound, together with lower amounts of $\mathrm{CA}_{2}$ (ICDD 07-0082) and $\mathrm{C}_{12} \mathrm{~A}_{7}$ (ICDD 09-0413): 52.1\% of CA, $25.5 \%$ of $\mathrm{C}_{12} \mathrm{~A}_{7}$ and $22.4 \%$ of $\mathrm{CA}_{2}$. For the metal load, highly soluble LiCl (Panreac), 
$\mathrm{LiNO}_{3}$ (Merck), $\mathrm{CrCl}_{3} \cdot 6 \mathrm{H}_{2} \mathrm{O}$ (Panreac), $\mathrm{Cr}\left(\mathrm{NO}_{3}\right)_{3} \cdot 9 \mathrm{H}_{2} \mathrm{O}$ (Panreac), $\mathrm{K}_{2} \mathrm{CrO}_{4}$ (Panreac), $\mathrm{ZnCl}_{2}$ (Panreac), $\mathrm{Zn}\left(\mathrm{NO}_{3}\right)_{2} \cdot 6 \mathrm{H}_{2} \mathrm{O}$ (Panreac), $\mathrm{Pb}\left(\mathrm{NO}_{3}\right)_{2}$ (Prolabo), $\mathrm{CuCl}_{2} \cdot 2 \mathrm{H}_{2} \mathrm{O}$ (Aldrich), and $\mathrm{Cu}\left(\mathrm{NO}_{3}\right)_{2} \cdot 3 \mathrm{H}_{2} \mathrm{O}$ (Merck) were chosen.

\subsection{Methods}

\subsubsection{Pastes preparation}

Pastes were prepared by dry mixing soluble salts with the calcium aluminate $(1 \mathrm{wt} . \%$ metal/calcium aluminate). We chose to test the $1 \mathrm{wt} . \%$ dosage in coherence with previous works by our research group testing the very same dosage and for comparative purposes $[2,15]$. This dose lies between lower dosages frequently used when metal salts were employed as setting modifiers and the higher ones reported by many other authors in works dealing with the influence of metals on the hydration of cementitious phases $[8,11,16,17]$.

Water was then added to get a water/calcium aluminate ratio of 0.4. Some control samples were also studied at different $w / c$ ratios: $0.40,0.55,0.70$ and 1.58 . The mixtures were blended by hand for $1 \mathrm{~min}$. All the hydration analyses were carried out at $20^{\circ} \mathrm{C}$. In order to carry out the analyses, sufficient amounts of each sample were collected at different times ( $5 \mathrm{~min}, 30 \mathrm{~min}, 120 \mathrm{~min}, 6 \mathrm{~h}, 48 \mathrm{~h}$ ). With the aim of removing all water and halting the ongoing hydration, samples were subjected to a freeze-drying procedure. The specimens were immersed in liquid $\mathrm{N}_{2}$ for $5 \mathrm{~min}$, and subsequently sublimated at $-40{ }^{\circ} \mathrm{C}$ under $1 \mathrm{~Pa}$ vacuum for $24 \mathrm{~h}$ [18]. After this, the pastes were maintained in a desiccator to avoid further hydration.

\subsubsection{Experimental measurements}


The effect of the addition of the different salts was studied following the appearance or disappearance of different crystalline phases and their shifts in the XRD patterns. The XRD experiments were performed in a Bruker D8 Advance diffractometer, under conditions of a step size of $0.102^{\circ}$ and $3 \mathrm{~s}$ time/step, from $2^{\circ}$ to $50^{\circ}$ (2-theta) with a CuKa1 radiation. A quantitative evaluation programme (EVA Diffrac Plus) was used and, in this case, a semi-quantitative method was followed based on the intensities of the main diffraction peak of each one of the crystalline phases identified.

Thermal studies and FTIR-ATR analyses were also executed to obtain information about the hydration of different calcium aluminates. TG and DTG curves were obtained thanks to the use of a simultaneous TG-SDTA 851 Mettler Toledo device. The thermal experiments were performed under the following conditions: $10^{\circ} \mathrm{C} / \mathrm{min}$ heating rate, from ambient temperature to $1000{ }^{\circ} \mathrm{C}$, alumina crucible, and static air atmosphere. Although the identification and precise quantification in calcium aluminate cement pastes is not easy due to overlap of individual decomposition processes, the mass loss up to $200{ }^{\circ} \mathrm{C}$ derived from thermogravimetric curves of samples was assigned to the water released from the dehydration of metastable phases (for example, $\mathrm{AH}_{3} \cdot \mathrm{xH}_{2} \mathrm{O}$ gel, $\mathrm{CAH}_{10}$ or $\mathrm{C}_{2} \mathrm{AH}_{8}$, as mentioned other authors [19-20]).

Mid-infrared spectra were taken at room temperature with a Nicolet-Avatar 360 FTIR spectrometer equipped with Golden Gate ATR accessory. For each sample, 100 scans were recorded in the $4000-600 \mathrm{~cm}^{-1}$ with a resolution of $4 \mathrm{~cm}^{-1}$.

The heat flow rate and total heat released during hydration of the pastes was determined by isothermal calorimetry. Measurements were conducted on a TAM Air conduction calorimeter. The pastes were previously stirred by hand with a glass rod for $3 \mathrm{~min}$ to get a proper degree of homogeneity. 


\section{Results and discussion}

\subsection{Lithium salts}

Fig. 2 shows the diffraction patterns of the control and Li-bearing samples. No significant diffraction signals were found below $10^{\circ} 2 \theta$. Crystallized metal-containing phases were never identified by XRD irrespective the metal salt and whatever the sample and the time of hydration (up to 48 hours). This could be due to a low metal content $(1 \%)$ to be detected by XRD, a low diffraction power of the phase formed or the precipitation as amorphous compounds undetectable by X-ray diffraction.

The diffraction signals of $\mathrm{CA}, \mathrm{C}_{12} \mathrm{~A}_{7}$ and $\mathrm{CA}_{2}$ were clearly observed for all the samples containing respectively $\mathrm{LiCl}$ and $\mathrm{LiNO}_{3}$. Although the diffraction reflections of, especially, $\mathrm{CA}$ and $\mathrm{CA}_{2}$ decreases sharply for binder when lithium salt was incorporated (see Figure 2, the peak intensity reduction between $5 \mathrm{~min}$ and $48 \mathrm{~h}$ for peaks at $2 \theta=$ $30.1^{\circ}$ for $\mathrm{CA}$ and at $25.5^{\circ}$ for $\mathrm{CA}_{2}$ ), there was not a complete hydration since significant amounts of anhydrous compounds still remaining unhydrated. It has been reported that $\mathrm{C}_{12} \mathrm{~A}_{7}$ hydration proceeds faster than that of the CA [21]. This fact could be proven in the semi-quantitative analysis of the intensities of the main diffraction peaks in the XRD patterns of the metal-free samples over the studied hydration time (Fig. 3, control sample). The intensities of the main diffraction peaks of the crystalline phases that were identified have been considered. For each compound, the ratio of intensity of its main peak (counts) related to the total intensity of the phases (total number of counts in arbitrary units) was depicted. The evolution of phases showed that the consumption of $\mathrm{C}_{12} \mathrm{~A}_{7}$ was significant in the first stages of the hydration of the control sample. At the same time, $\mathrm{CA}$ and $\mathrm{CA}_{2}$ showed, if any, little changes: the increase is due to the higher ratio preponderance of these phases as a consequence of the $\mathrm{C}_{12} \mathrm{~A}_{7}$ consumption. There was no evidence of the formation of crystalline hydrates. To confirm these findings, a 
detailed examination of control samples with different $w / c$ ratios $(0.40,0.55,0.70$ and 1.58) was carried out by XRD (Fig. 4). From these experiments, it can be confirmed that consumption of $\mathrm{C}_{12} \mathrm{~A}_{7}$ was significant in comparison with both $\mathrm{CA}$ and $\mathrm{CA}_{2}$. The higher the amount of mixing water, the more intense the $\mathrm{C}_{12} \mathrm{~A}_{7}$ consumption. Additionally, only in samples with the highest content in water $(\mathrm{w} / \mathrm{c}=1.58)$ traces of hydrated crystalline phases were found, belonging to stable hydrates (very small traces of $\mathrm{C}_{3} \mathrm{AH}_{6}$ and $\mathrm{AH}_{3}$, after 48 hours). There was no evidence of the presence of crystalline metastable hydrates, such as $\mathrm{CAH}_{10}$ or $\mathrm{C}_{2} \mathrm{AH}_{8}$. Nevertheless, the ongoing of the hydration was clearly sustained by the fact that the intensity of the diffraction peaks corresponding to anhydrous phases $\left(\mathrm{CA}\right.$ and $\left.\mathrm{C}_{12} \mathrm{~A}_{7}\right)$ clearly reduced when the ratio w/c increases at different times. The absence of crystalline peaks of metastable hydrates suggests the poor crystallinity of the phases and/or their scarce amount. It was obvious that the characteristics of the CA obtained by solid-state reaction used in the current work did not favour the formation of crystalline compounds, conversely to the reported behaviour of some calcium aluminate cements.

However, Fig. 3 shows that, in the presence of lithium salts, and according to the ratio of the anhydrous compounds, $\mathrm{CA}$ and $\mathrm{CA}_{2}$ reacted quicker than $\mathrm{C}_{12} \mathrm{~A}_{7}$. The consumption of $\mathrm{CA}$ and $\mathrm{CA}_{2}$ was clear at the first stages of the hydration (specially until 6 hours), whereas the ratio of $\mathrm{C}_{12} \mathrm{~A}_{7}$ underwent an increase owing to the faster progressive disappearance of $\mathrm{CA}$ and $\mathrm{CA}_{2}$. This point will be discussed further on.

Regarding hydrated phases, there is no clear evidence of crystalline hydrates such as $\mathrm{C}_{2} \mathrm{AH}_{8}$ or $\mathrm{CAH}_{10}$ that could be expected as metastable compounds: certain damage to the crystallinity of the $\mathrm{CAH}_{10}$ phases owing to the freeze-drying process to arrest the hydration could partially account for this fact [22]. However, peaks of hydrated phases belonging to the AFm phases $\left(\mathrm{C}_{4} \mathrm{~A}\right.$ hydrates $)$ were clearly identified. These hydrated 
compounds present a lamellar double hydroxide structure [23] and are structurally related to the mineral hydrocalumite [24-25]. Although there are discrepancies concerning the amount of water as a function of the different conditions, $\mathrm{C}_{4} \mathrm{AH}_{13}$ seems to be the compound obtained under usual RH conditions [23]. When $\mathrm{LiCl}$ was present, a Cl-AFm (Friedel's salt) compound was identified by its main diffraction signals at 11.2 and $22.6^{\circ} 2 \theta$ [26]. Note that AFm compounds are able to uptake anions such as chloride, nitrate or carbonate within the interlayer space to balance the excess of positive charge of the cationic layers [27]. If the paste was prepared with $\mathrm{LiNO}_{3}$, then a $\mathrm{NO}_{3}-\mathrm{AFm}$ compound was found. In this case, the diffraction signals suffered a shift towards lower $2 \theta$ values, showing signals at 10.1 and $20.9^{\circ} 2 \theta$ [28].

Thermal analyses were carried out to study the thermal decomposition of the samples. The control samples (with different w/c ratios) depicted very similar TG patterns after $48 \mathrm{~h}$ (Fig. 5). Table 1 collects the weight loss percentages ascribed to the decomposition effects described below for the control samples with different w/c ratios. DTG pattern of the control sample can be observed in Fig. 6. The weight loss at ca. $70^{\circ} \mathrm{C}$ was ascribed to the dehydration of alumina gel, $\mathrm{Al}_{2} \mathrm{O}_{3} \cdot \mathrm{xH}_{2} \mathrm{O}$, which usually takes place below $100^{\circ} \mathrm{C}$ (temperature range $25-100^{\circ} \mathrm{C}$ in Table 1). Note that this peak (Fig. 6) was overlapped with the peak at ca. $137^{\circ} \mathrm{C}$, which was ascribed to the decomposition of phases with composition approximately $\mathrm{CAH}_{10}[19,29]$ (temperature range $100-200^{\circ} \mathrm{C}$ in Table 1$)$. It has to be noticed that no crystalline diffraction peaks of $\mathrm{CAH}_{10}$ were found.

The weight losses represented by the DTG peaks at ca. $260^{\circ} \mathrm{C}$ and $440^{\circ} \mathrm{C}$ of the control sample in Fig. 6 can be ascribed to the decomposition of $\mathrm{AH}_{3}$ (temperature range 200$340^{\circ} \mathrm{C}$ in Table 1) and $\mathrm{C}_{3} \mathrm{AH}_{6}$ (temperature range $340-550^{\circ} \mathrm{C}$ in Table 1) phases (in the last case, also the decomposition of $\mathrm{CH}$ traces could contribute to this peak) [30,31]. Finally, the DTG peak at ca. $700^{\circ} \mathrm{C}$ was related to the decomposition of carbonates [20] 
(temperature range $550-1000^{\circ} \mathrm{C}$ in Table 1). Therefore, the experimental results of the control samples showed that their hydration led to the formation of mainly amorphous phases matching, according to the TG-DTG results, the composition of hydrated phases reported in studies on $\mathrm{CAC}$ hydration: alumina gel, $\mathrm{CAH}_{10}, \mathrm{AH}_{3}$ and $\mathrm{C}_{3} \mathrm{AH}_{6}$.

When the lithium salts were added, it was found that the weight loss after $48 \mathrm{~h}$ in the range of $25-200^{\circ} \mathrm{C}$ was larger for samples with $\mathrm{LiCl}(9.18 \%)$ or $\mathrm{LiNO}_{3}(6.93 \%)$ than that for plain samples $(5.32 \%)$, matching the identification of hydrated compounds by XRD.

In addition, DTG curves analysis in Fig. 6 showed several differences in the curves. In samples treated with lithium salts, the most important phenomena in DTG curves are those derived from the presence of AFm phases, which were the dominant hydrates. After the addition of $\mathrm{LiCl}$, two marked DTG peaks are found at $150{ }^{\circ} \mathrm{C}$ and $270^{\circ} \mathrm{C}$, approximately matching with those described for AFm compounds [27]: the first DTG peak was due to the release of interlayer water while the second peak was ascribed to the loss of the remaining water. The shoulder at ca. $202^{\circ} \mathrm{C}$ could be related to small amounts of $\mathrm{C}_{2} \mathrm{AH}_{8}$, a metastable hydrate that was not observed by XRD [29].

The DTG analysis of samples after the addition of $\mathrm{LiNO}_{3}$ showed a thermal decomposition that matches the thermal decomposition of $\mathrm{NO}_{3}$-AFm phases [28,32], confirming its presence as the dominant hydrate as evidenced by XRD. These processes were: (i) a first dehydration at ca. $110^{\circ} \mathrm{C}$. Note that this temperature decomposition shifted towards lower temperatures in comparison with the first dehydration peak of ClAFm phases [32]; (ii) a sharp peak at ca. $250^{\circ} \mathrm{C}$ due to the formation of nitrite in the AFm phase via decomposition of nitrate; and (iii) decomposition of nitrite at temperatures of ca. $520^{\circ} \mathrm{C}$ [28]. As in the case of LiCl-bearing samples, the presence of $\mathrm{C}_{2} \mathrm{AH}_{8}$ denoted by its decomposition at ca. $200^{\circ} \mathrm{C}$ cannot be ruled out. 
In the same way than in control samples, in samples with Li salts peaks at temperatures higher than $600^{\circ} \mathrm{C}$ can be ascribed to decomposition of carbonates.

These findings in samples treated with lithium salts are in good agreement with thermal decomposition data reported for $\mathrm{Cl}-\mathrm{AFm}$ and $\mathrm{NO}_{3}$-AFm phases, respectively [27-28], and confirm the formation of these hydrocalumite-like phases observed by XRD results. Infrared spectra registered also confirmed these findings. For these studies, the assignment of the different absorption bands was made as follows: the absorption region due to vibration of $\mathrm{O}-\mathrm{H}$ groups $\left(4000-3000 \mathrm{~cm}^{-1}\right.$, with maximum at ca. $\left.3475 \mathrm{~cm}^{-1}\right)$ was analysed and associated to hydrated calcium aluminate compounds, together with bands at ca. $1022 \mathrm{~cm}^{-1}$, also assigned to $\mathrm{OH}$ stretching vibrations for $\mathrm{AH}_{3}$ [33]. The signal at ca. $780 \mathrm{~cm}^{-1}$ was ascribed to vibrations of $\mathrm{AlO}_{4}$ groups, being the bands at about 680 and $640 \mathrm{~cm}^{-1}$ assigned to $\mathrm{AlO}_{6}$ vibrations [19,27,29].

The absorption band at ca. $1415 \mathrm{~cm}^{-1}$ could be assigned to the presence of $\mathrm{CO}_{2}$ on the product surface or carbonate impurities embedded in the crystal structure, corresponding to the stretching vibrations of the $\mathrm{CO}_{3}{ }^{2-}$ group in calcite-type compounds $[19,26,29]$.

In Fig. 7, after $48 \mathrm{~h}$, the control sample showed a weak absorption band at $3475 \mathrm{~cm}^{-1}$ and peaks at $780 \mathrm{~cm}^{-1}$ and the doublet at 680 and $640 \mathrm{~cm}^{-1}$, which can be ascribed to the rather limited presence of calcium aluminate hydrates elucidated by TG-DTG analysis.

In this Fig. 7, in a semi-quantitative estimation, clearly higher amounts of hydrated compounds in calcium aluminate binders containing both lithium chloride and lithium nitrate were observed by the higher intensities of the absorption bands at the spectral ranges of $3000-4000 \mathrm{~cm}^{-1}$ and ca. $1000 \mathrm{~cm}^{-1}$. In these Li-bearing samples, the peak at $1621 \mathrm{~cm}^{-1}$ shows the $\mathrm{H}-\mathrm{O}-\mathrm{H}$ bending vibration of the adsorbed water molecule, 
described for AFm phases [34]. In the sample with $\mathrm{LiNO}_{3}$, the anti-symmetric stretching vibration of $\mathrm{NO}_{3}{ }^{-}$was evidenced by sharp split peaks at ca. $1380 \mathrm{~cm}^{-1}$ and $1340 \mathrm{~cm}^{-1}$. These peaks could be checked in all nitrate-bearing samples. Note that chloride absorption bands could not be seen in the range $4000-600 \mathrm{~cm}^{-1}$, due to the ionic nature of its bond [34].

It appears to be evident that the incorporation to the CA of lithium salts, both with chloride as well as nitrate as counterions, accelerate the hydration process as compared with salt-free systems. These results are in good agreement with previous works dealing with the accelerating role of lithium salts in CAC systems [8-11,22].

As shown in Fig. 8, the heat flow curves of the samples confirmed the accelerating role of the lithium salts. In the control sample (salt-free), a first, intense exothermic signal can be observed at the beginning of the water addition: this heat evolution is usually related to the cementitious compounds dissolution, in which the fast dissolution of the anhydrous calcium aluminate has to be mentioned [35]. Then, a plateau was achieved in the so-called induction period. During this period, it has been reported that aluminium concentration (as $\mathrm{Al}(\mathrm{OH})_{4}{ }^{-}$owing to the alkaline $\mathrm{pH}$ of the dissolution) reached the highest level [22]. The nucleation and growth of $\mathrm{AH}_{3}$ took place during this period. Finally, another exothermic peak, ascribed to the massive precipitation of hydrates, was observed after 7.6 hours. This result is in line with that previously published for pure CA hydration [5].

When lithium salts were added, the heat flow curves showed a very distinct pattern. A more intense heat evolution happened after a short period of time (first 5 minutes), probably overlapped with the contribution of the anhydrous compounds dissolution. No more peaks of heat evolution were observed. The presence of lithium salts dramatically 
shortened the induction period, and the massive precipitation of hydrates took place during the first minutes.

One of the hypotheses, according to previous works dealing with the role of lithium compounds on the CAC hydration, is that the presence of lithium salts seems to change the calcium/aluminium ratio of concentrations in the solutions. Apparently, the precipitation of lithium hydro-meta-aluminate causes a severe reduction of $\mathrm{Al}$ concentration and a subsequent increase in the C/A ratio [10].

Results of the current work also agree with this hypothesis. In the presence of Li salts, the increase in $\mathrm{C} / \mathrm{A}$ ratio shifted the solution composition (in the ternary $\mathrm{CaO}-\mathrm{Al}_{2} \mathrm{O}_{3}$ $\mathrm{H}_{2} \mathrm{O}$ system $\left.[10,36,37]\right)$ towards the supersaturation region of $\mathrm{C}_{4} \mathrm{~A}$ hydrates, which would explain the formation of these AFm phases, as here clearly evidenced by XRD and thermal analysis. The nucleation barrier was thus lowered explaining the acceleration of the hydration process of CA, either by the formation of these AFm hydrates themselves or by their action as heterogeneous nucleation substrates that would shorten the induction period. In the same line, it has been reported that: (i) the nucleation of one or more of the metastable hydrates is the rate controlling factor in the early hydration of CAC based calcium monoaluminate [38]; (ii) Ca-rich hydrates were found in $\mathrm{CAC}$ samples treated with $\mathrm{LiCl}$ [39], and (iii) the formation of $\mathrm{AFm}$ phases would promote the $\mathrm{C}_{2} \mathrm{AH}_{8}$ nucleation, explaining its finding in lithium-treated CAC samples [22].

In experimental support of this explanation, besides the identification of AFm phases (Cl-AFm or $\mathrm{NO}_{3}-\mathrm{AFm}$, depending on the anionic counterion), it has been proven and discussed above by XRD that the usually slower dissolution of the Al-enriched phases $\left(\mathrm{CA}\right.$ and $\left.\mathrm{CA}_{2}\right)[21,40]$ was favoured in the presence of Li compounds: the precipitation of $\mathrm{Al}$ by lithium promotes a faster dissolution of $\mathrm{CA}$ and $\mathrm{CA}_{2}$, as compared with the 
dissolution of the calcium-enriched phase $\left(\mathrm{C}_{12} \mathrm{~A}_{7}\right)$, whose reactivity (fast in absence of lithium salts) underwent a slowdown as a consequence of the large C/A ratio.

\subsection{Chromium(III) salts}

According to XRD patterns that can be seen in Fig. 9, the presence of $\mathrm{CrCl}_{3}$ or $\mathrm{Cr}\left(\mathrm{NO}_{3}\right)_{3}$ in the samples gave rise to the formation of AFm phases: the Cl-AFm phase was clearly identified by diffraction signals at $11.4^{\circ}$ and $22.62 \theta$, corresponding to its main diffraction peaks, while the $\mathrm{NO}_{3}$-AFm phase formation was proven by the peaks at $10.2^{\circ}$ and $20.9^{\circ} 2 \theta$. Similarly to the effect caused by lithium salts, the identification of AFm phases owing to the presence of the metallic salt suggests their role in the modification of the hydration kinetics.

The heat flow curves confirmed the accelerating role of the $\mathrm{Cr}(\mathrm{III})$ salts tested in the current work (Fig. 10). The patterns of these curves were similar to those obtained for Li salts. A strong heat evolution was found at a very short period of time (very few minutes after the water addition). These curves showed that the induction period was dramatically shortened in the presence of Cr(III) salts. As in the case of Li salts, the peak was probably overlapped with the heat evolution accounting for the anhydrous compounds dissolution. There was no evidence of other exothermic phenomena over the next 30 hours.

The accelerating action of the Cr(III) salts was further confirmed by thermal analysis and FTIR studies. The results provided by thermal analysis showed a higher amount of water loss belonging to the hydrated calcium aluminate phases when chromium salts were present in the samples: after $48 \mathrm{~h}$, the weight loss values in the range of $25-200^{\circ} \mathrm{C}$, ascribed to dehydration of calcium aluminate hydrates, were higher for $\mathrm{CrCl}_{3}(8.36 \%)$ 
or $\mathrm{Cr}\left(\mathrm{NO}_{3}\right)_{3}(6.63 \%)$ than that for plain samples $(5.32 \%)$. For samples treated with $\mathrm{CrCl}_{3}$, DTG curve after $48 \mathrm{~h}$ (Fig. 11) evidenced similar decomposition peaks than that reported for $\mathrm{LiCl}$ samples, in which the presence of $\mathrm{Cl}-\mathrm{AFm}$ as the dominant hydrate was clear: two main peaks appeared, belonging to the Cl-AFm decomposition: the first at ca. $150^{\circ} \mathrm{C}$ and the second one at ca. $260^{\circ} \mathrm{C}$. In samples with the addition of $\mathrm{Cr}\left(\mathrm{NO}_{3}\right)_{3}$, the first peak appeared at lower temperature $\left(110^{\circ} \mathrm{C}\right)$, matching the thermal behaviour of $\mathrm{NO}_{3}$-AFm phases. Decomposition of nitrate giving rise to nitrite formation and decomposition of nitrite (peaks at 265 and $530^{\circ} \mathrm{C}$, respectively) were also checked.

The results by infrared spectroscopy also agree with those provided for the other techniques. The bands corresponding to $-\mathrm{OH}$ groups (at ca. 3500 and $1200 \mathrm{~cm}^{-1}$ ) were more intense for those CA samples in which chromium salts had been incorporated (Fig. 12, samples after $48 \mathrm{~h}$ ) (see the zoom in Fig. 12 for the absorption band at ca. 3475 $\mathrm{cm}^{-1}$ ). Similarly to the Li-treated samples, the band at $1621 \mathrm{~cm}^{-1}$ was ascribed to AFm phases and in the sample with nitrate the sharp split peaks at ca. $1380 \mathrm{~cm}^{-1}$ and 1340 $\mathrm{cm}^{-1}$ were also observed.

This accelerating role of $\mathrm{Cr}(\mathrm{III})$ salts is here reported for the first time. XRD patterns also were in accordance with this finding. It can be observed that, in the presence of $\mathrm{Cr}$ (III) salts, $\mathrm{C}_{12} \mathrm{~A}_{7}$ anhydrous phases showed a reduction in the intensities of the peaks along time in a stronger way than in the salt-free sample. Conversely to the lithium salts XRD patterns, in salt-treated samples, $\mathrm{C}_{12} \mathrm{~A}_{7}$ showed a faster reactivity as compared with $\mathrm{CA}$ and $\mathrm{CA}_{2}$. These results were evident for $\mathrm{Cr}(\mathrm{III})$-bearing samples, as depicted in Fig. 13, in which a clear reduction in the intensities of $\mathrm{C}_{12} \mathrm{~A}_{7}$ peaks could be checked.

Therefore, experimental findings proved that the presence of $\mathrm{Cr}(\mathrm{III})$ favoured the formation of AFm phases (hydrocalumite-like structures). These facts resulted in an accelerating role of $\mathrm{Cr}$ (III) salts, as confirmed by the heat flow curves, very similar to 
that achieved by lithium salts. The similarities between $\mathrm{Al}^{3+}$ and $\mathrm{Cr}^{3+}$ ions have to be taken into account. $\mathrm{Cr}^{3+}$ cations can substitute $\mathrm{Al}^{3+}$ in many calcium aluminate compounds, as reported by Kindness and co-workers [41]. In reactions of $\mathrm{Cr}$ (III) salts with tricalcium aluminate, these authors proved the obtaining of isostructural calcium aluminate hydrates with high amount of $\mathrm{Ca}$, arising from $\mathrm{Cr}$-substituted compounds, in which $\mathrm{Cr}(\mathrm{III})$ partially replaces $\mathrm{Al}(\mathrm{III})$. These hydrates belong to the $\mathrm{C}_{4} \mathrm{~A}$ family (for example, $\mathrm{Ca}_{2} \mathrm{Al}(\mathrm{OH})_{7} \cdot 6.5 \mathrm{H}_{2} \mathrm{O} / 0.5\left(4 \mathrm{CaO} \cdot \mathrm{Al}_{2} \mathrm{O}_{3} \cdot 13 \mathrm{H}_{2} \mathrm{O}\right)$, ICDD 16-0339). With respect to the role of the cation, the formation of AFm hydrates has been explained on the basis of the stabilization of the crystal structure due to the replacement of some $\mathrm{Ca}^{2+}$ ions by low-sized cations such as $\mathrm{Al}^{3+}$ or $\mathrm{Cr}^{3+}$ [42]. It can be proposed that, in the presence of $\mathrm{Cr}$ (III) salts, the precipitation of AFm and Cr-substituted compounds was favoured, being these compounds responsible for the short setting time of these Cr-bearing samples. This mechanism also justifies the faster reaction of $\mathrm{C}_{12} \mathrm{~A}_{7}$ in comparison with samples with Li salts, as shown in Fig. 13: the reduction in C/A ratio owing to the formation of the aforementioned hydrates with high ratio of $\mathrm{Ca}$ would promote the dissolution of calcium-rich anhydrous compounds, such as $\mathrm{C}_{12} \mathrm{~A}_{7}$.

The presence of the counterion, either chloride or nitrate, is also helpful as adjuvants to allow the formation of AFm phases (being chloride or nitrate the anion in the interlayer). In this line, the formation of these AFm phases has been reported to be preferred considering their ability to depress the free energy of the system [28]. Thermodynamic calculations referring to solubility constants of Cl-AFm [27] or $\mathrm{NO}_{3}$ AFm [28] evidenced the low solubility products of these phases explaining their preferred formation in the face of other calcium aluminate hydrates across a wide range of temperatures and anion concentrations [28]. 


\subsection{Chromium(VI) salts}

The addition of chromium(VI) salts provoked in the XRD patterns the appearance of small amounts of AFm phases at $2 \theta=11.6^{\circ}$ (see Fig. 13). The diffraction peaks of the main anhydrous component, $\mathrm{CA}$, showed that its rate of consumption increased with respect to the control sample.

The heat flow curves (Fig. 10) showed that the presence of chromate anions resulted in a slight reduction of the induction period, thus causing that the main heat release took place at early ages (6.05 hours in the face of 7.65 hours for control samples). This slight accelerating action was further proven by the larger degree of hydration of $\mathrm{Cr}(\mathrm{VI})$ treated samples in comparison with control samples as evidenced by thermal and FTIR analyses. By TG, the weight loss calculated at stage I of the dehydration yielded a value of $5.52 \%(5.32 \%$ for control samples $)$. In the case of samples treated with chromate anions, the DTG curve after $48 \mathrm{~h}$ (Fig. 11) was similar to that reported for $\mathrm{CrCl}_{3}$, determined by the presence of AFm phases, with two main peaks at ca. $150^{\circ} \mathrm{C}$ and a very sharp peak at $270^{\circ} \mathrm{C}$, ascribed to the dehydration of $\mathrm{AFm}$. In this last peak also the decomposition of $\mathrm{AH}_{3}$ could take place, explaining the intensity of this weight loss owing to the overlapping. The presence of DTG peaks at temperatures of ca. $440^{\circ} \mathrm{C}$ and $700^{\circ} \mathrm{C}$ matches the pattern of the control sample, in connection with the presence of $\mathrm{C}_{3} \mathrm{AH}_{6}$ and carbonates. The FTIR spectra after $48 \mathrm{~h}$ (Fig. 12) showed more intense absorption bands in $\mathrm{Cr}(\mathrm{VI})$-bearing samples as compared with the control sample in the regions related to calcium aluminate hydrates, particularly O-H groups $\left(4000-3000 \mathrm{~cm}^{-}\right.$ $\left.{ }^{1}\right)$ and $\mathrm{OH}$ stretching vibrations $\left(1022 \mathrm{~cm}^{-1}\right)$.

As in the previous discussions, the appearance of AFm phases seems to be tightly connected with the acceleration of the hydration of anhydrous CA. In this case, the $\mathrm{CrO}_{4}{ }^{2-}$ anions can be incorporated into the interlayer space of the hydrocalumite-like 
compound, giving rise to a signal in the XRD pattern, in good agreement with several previous works [43-45].

\subsection{Zinc salts}

Literature about the effect of $\mathrm{Zn}$ when incorporated to cement and cementitious compounds displayed contradictory results. In Portland cement, $\mathrm{Zn}$ has been reported to show a deleterious effect, delaying dramatically the setting time and causing a severe decrease in mechanical strength [16]. In CAC systems, some controversial data have been reported: while $\mathrm{ZnCl}_{2}$ has been said to be a strong retarder [11], $\mathrm{Zn}\left(\mathrm{NO}_{3}\right)_{2}$ has been identified as an accelerator of the setting [2,9]. In calcium sulfoaluminate cements, $\mathrm{Zn}^{2+}$ was found to act shortening the setting time, although in this type of cements the effect of the counterion was proven to be essential [17].

Results by XRD in Fig. 14 showed that addition of zinc chloride in the binders provoked a slight reduction of the intensities corresponding to the anhydrous CA and $\mathrm{C}_{12} \mathrm{~A}_{7}$. In comparison with $\mathrm{Li}(\mathrm{I})$ and $\mathrm{Cr}(\mathrm{III})$ salts, the rate of, respectively, $\mathrm{CA}$ and $\mathrm{C}_{12} \mathrm{~A}_{7}$ consumption was generally less marked.

The heat flow curves of samples treated with Zn salts are depicted in Fig. 15. Both Zn compounds showed sharp peaks corresponding to the massive precipitation of hydrates, quantitatively similar. Both salts shortened the induction period: $\mathrm{ZnCl}_{2}$ slightly reduced the induction period in comparison with the control sample resulting in a $t_{\max }$, time of the maximum of the heat release peak, of $7.16 \mathrm{~h}$ ( 7.65 for the control sample), whereas $\mathrm{Zn}\left(\mathrm{NO}_{3}\right)_{2}$ gave rise to a more intense reduction, $\mathrm{t}_{\max }=3.64 \mathrm{~h}$. It can be thus concluded that zinc chloride as well as zinc nitrate acted as accelerators when added to CA samples, shortening the induction period. This finding is in line with results published 
by Berger et al. [17] for calcium sulfoaluminate cement and by our group for calcium aluminate cements [2], in which $\mathrm{Zn}\left(\mathrm{NO}_{3}\right)_{2}$ was seen to shorten the setting time of these cementitious materials. Another agreement can be mentioned regarding the moderate level of hydration that was observed for $\mathrm{CA}$ and $\mathrm{CA}_{2}$ : this fact matches the $\mathrm{XRD}$ analysis of $\mathrm{CAC}$ with $\mathrm{Zn}\left(\mathrm{NO}_{3}\right)_{2}$ published in [2], and would explain the moderate decrease in compressive strengths observed for these samples when compared with plain samples.

As in the case of the $\mathrm{Li}$ and $\mathrm{Cr}$ salts that were also seen to act as accelerators, XRD results allowed us to observe the formation of AFm phases in $\mathrm{Zn}$-treated samples (see, as an example, the XRD pattern of a $\mathrm{Zn}\left(\mathrm{NO}_{3}\right)_{2}$ sample in Fig. 16). As a matter of fact, the most intense diffraction signal appeared at ca. $11.4^{\circ} 2 \theta$, irrespective of the anion. This finding points to an accelerating mechanism in which the formation of AFm phases plays a relevant role. These hydrocalumite-like structures in the presence of $\mathrm{Zn}^{2+}$ would be formed as they are the dominant phases under the experimental conditions as a consequence of their extremely low solubility product [46]: this fact is supported by previous results reporting the formation of the same hydrocalumite-based compound ( $\mathrm{ZnAl}-\mathrm{Cl}-\mathrm{LDH})$ when either $\mathrm{ZnCl}_{2}$ or $\mathrm{Zn}\left(\mathrm{NO}_{3}\right)_{2}$ were added [47]. In the experimental results of the current work and in line with this fact, XRD patterns depicted the same diffraction signals for the AFm phase, when either $\mathrm{ZnCl}_{2}$ or $\mathrm{Zn}\left(\mathrm{NO}_{3}\right)_{2}$ was added and Thermal analysis of samples treated with Zn salts depicted very similar DTG patterns after $48 \mathrm{~h}$ (Fig. 17). The decomposition peaks at ca. $140^{\circ} \mathrm{C}$ and $270^{\circ} \mathrm{C}$ (decomposition of AFm) confirmed the finding of similar AFm phases by XRD. In this case, irrespective of the anion, both samples yielded the same hydrocalumite-like structure. The formation of partially substituted AFm phases under the presence of $\mathrm{Zn}$ had been also reported in similar systems by Berger et al. [17]. 
It can be assumed that, after the precipitation of AFm phases, the subsequent reduction in $\mathrm{C} / \mathrm{A}$ ratio promoted the dissolution and ulterior hydration of Ca-rich anhydrous phases, such as $\mathrm{C}_{12} \mathrm{~A}_{7}$, explaining its intensity reduction in the peaks observed by XRD, similarly to the mechanism explained above for $\mathrm{Cr}(\mathrm{III})$ salts.

The primary formation of these AFm compounds would explain the stiffening of the samples (setting time reduction as estimated by the workable life in CAC systems [2]) and the main peak of the heat evolution (heat flow curves). At the same time, and in an apparent self-contradiction, the precipitation of these hydrates could render a protective coating on the anhydrous $\mathrm{CA}$ and $\mathrm{CA}_{2}$ particles, preventing them from hydration (similarly to the self-limited CA reaction by a protective layer of $\mathrm{AH}_{\mathrm{x}}$-gel [40]): these would explain the lower accumulative heat evolution of these samples as compared with control samples (see cumulative heat curves in Fig. 15) and the relatively low degree of hydration of $\mathrm{CA}$ and $\mathrm{CA}_{2}$ phases (Fig. 14). To uphold this statement, it can be seen by XRD that Zn-AFm hydrates were checked also after 48 hours (Fig. 16), a fact that demonstrates the stability of this compound owing to its low Kps. Moreover, by FTIR (Fig. 18) it can be seen that absorption bands ascribed to the formation of hydrated compounds are, from a semi-quantitative point of view, similar to those of the control sample, proving the low degree of hydration of the different anhydrous phases, such as $\mathrm{CA}_{2}$. In comparison with the control sample, DTG curves showed that the weight losses above $200^{\circ} \mathrm{C}$ were lower, suggesting the limited hydration of the samples with $\mathrm{Zn}$ salts.

\subsection{Lead salts}

In the case of lead salts, only $\mathrm{Pb}\left(\mathrm{NO}_{3}\right)_{2}$ was tested, avoiding the use of $\mathrm{PbCl}_{2}$ owing to its very low solubility product in water, which could lead to an anomalous behaviour. 
As can be observed in Fig. 14, in samples containing $\mathrm{Pb}\left(\mathrm{NO}_{3}\right)_{2}$, intensities of the anhydrous components showed little changes along time.

It seems that $\mathrm{Pb}\left(\mathrm{NO}_{3}\right)_{2}$ hindered the hydration of the anhydrous calcium aluminates. This fact was confirmed in Fig. 15 (heat flow curves) by the isothermal calorimetric measurements, in which the main peak of heat evolution appeared at 10.70 hours, while in the control sample was identified at 7.65 hours. This retarding effect of $\mathrm{Pb}\left(\mathrm{NO}_{3}\right)_{2}$ is in good agreement with previous results in OPC as well as in CAC, where the presence of $\mathrm{Pb}^{2+}$ was always detrimental to the setting and compressive strengths of the samples $[2,48,49]$. Thermogravimetric results also confirmed this fact, yielding a low hydration degree (5.24\% of weight loss vs. $5.32 \%$ for control sample). DTG curve after $48 \mathrm{~h}$ was very similar to that of the control sample (Fig. 19): small peak at ca. $70^{\circ} \mathrm{C}$, ascribed to the dehydration of alumina gel; peak at ca. $140^{\circ} \mathrm{C}$, which can be related to $\mathrm{CAH}_{10}$ and peak at $260^{\circ} \mathrm{C}$, ascribed to dehydration of $\mathrm{AH}_{3}$. In this sample, the peak at $430^{\circ} \mathrm{C}$ was negligible, showing the lower degree of hydration of this sample as compared with the control group. The decomposition of nitrate at $270^{\circ} \mathrm{C}$ to yield nitrite was overlapped to the $\mathrm{AH}_{3}$ dehydration peak resulting in a more intense DTG peak. The decomposition of nitrite was also observed at ca. $520^{\circ} \mathrm{C}$. Negligible variations between $\mathrm{Pb}$-treated and plain samples can be reported concerning the FTIR analysis (Fig. 20).

In this case, there is no clear evidence of the formation of AFm (hydroxy or nitrateAFm) that could hypothetically contain $\mathrm{Pb}^{2+}$ ions (Fig. 16) and the delay in the hydration can be explained considering that $\mathrm{Pb}$ hydroxides are of very low solubility at the $\mathrm{pH}$ of the CA media, showing less amphoteric character than other hydroxides (for example, $\mathrm{Zn}$ ). Therefore, $\mathrm{Pb}$ hydroxides were more likely to appear as precipitates giving rise to a coating on the phase boundary surface of cement grains [2]. The 
formation of this insoluble coating would block hydrolysis and inhibit growth of the crystalline hydration products.

Literature confirms the poor affinity of $\mathrm{Pb}^{2+}$ for calcium aluminate compounds and the formation of oxo- and hydroxyl-compounds [44].

\subsection{Copper salts}

The two copper salts showed a much reduced rate of hydration of the anhydrous phases as can be seen by XRD in Fig. 14. All the diffraction peaks of $C A, C_{2}$ and $\mathrm{C}_{12} \mathrm{~A}_{7}$ could be checked with negligible changes with respect to the non-hydrated sample. There was not clear evidence of the formation of crystalline calcium aluminate hydrates (see, as an example, the XRD pattern of $\mathrm{Cu}\left(\mathrm{NO}_{3}\right)_{2}$ sample in Fig. 16). DTG curves after $48 \mathrm{~h}$ were, as in the case of $\mathrm{Pb}$ salts, very similar to that of the control sample (Fig. 19). In these samples, the peak at $430^{\circ} \mathrm{C}$ was negligible, showing the lower degree of hydration of these samples as compared with the control group. In the sample treated with $\mathrm{Cu}\left(\mathrm{NO}_{3}\right)_{2}$, the decomposition of nitrite was also observed in a small DTG peak at ca. $520^{\circ} \mathrm{C}$.

FTIR results depicted in Fig. 20 also confirmed the absence of significant hydration of the anhydrous calcium aluminates. The heat flow curves (Fig. 15) showed a main peak dramatically shifted towards higher periods of time, involving a strong delay in the hydration process: the presence of either $\mathrm{CuCl}_{2}$ or $\mathrm{Cu}\left(\mathrm{NO}_{3}\right)_{2}$ increased the induction period: $\mathrm{t}_{0} 10.46$ hours and $\mathrm{t}_{\max } 15.31 \mathrm{~h}$ for $\mathrm{CuCl}_{2}, \mathrm{t}_{0} 10.10 \mathrm{~h}$ and $\mathrm{t}_{\max } 13.97 \mathrm{~h}$ for $\mathrm{Cu}\left(\mathrm{NO}_{3}\right)_{2}$, in comparison with $\mathrm{t}_{0} 6.62 \mathrm{~h}$ and $\mathrm{t}_{\max } 7.65 \mathrm{~h}$ for control sample. The cumulative heat evolution (Fig. 15) was lower for $\mathrm{Cu}$-treated samples than that for the control sample: after 48 hours, $500.15 \mathrm{~J} / \mathrm{g} 489.26 \mathrm{~J} / \mathrm{g}$ for $\mathrm{CuCl}_{2}$ and $\mathrm{Cu}\left(\mathrm{NO}_{3}\right)_{2}$, respectively, whereas control sample yielded $578.86 \mathrm{~J} / \mathrm{g}$. These findings are in line with 
the detrimental effect reported for $\mathrm{CAC}$ mortars treated with $\mathrm{Cu}(\mathrm{II})$ salts [2], which showed no mechanical strength and a strong delay in the setting time.

As discussed in the case of $\mathrm{Pb}$ salts, the insolubility and low amphoteric character of the copper hydroxides would explain this behaviour [2]. The formation of a coating of insoluble $\mathrm{Cu}$-hydroxides on the surface of the anhydrous particles hindered their hydration.

\section{Conclusions}

According to the experimental results, the addition of different metal salts to anhydrous calcium aluminates has a strong influence on the hydration kinetics at early stages: $\mathrm{LiCl}, \mathrm{LiNO}_{3}, \mathrm{CrCl}_{3}$ and $\mathrm{Cr}\left(\mathrm{NO}_{3}\right)_{3}$ caused a strong acceleration of the hydration with an early heat evolution. The addition of $\mathrm{K}_{2} \mathrm{CrO}_{4}, \mathrm{ZnCl}_{2}$ and $\mathrm{Zn}\left(\mathrm{NO}_{3}\right)_{2}$ slightly accelerates the hydration of the anhydrous components. Nevertheless, $\mathrm{Pb}\left(\mathrm{NO}_{3}\right)_{2}, \mathrm{CuCl}_{2}$ and $\mathrm{Cu}\left(\mathrm{NO}_{3}\right)_{2}$ caused a delay in the hydration as compared with the control (metal-free) sample.

In the case of the accelerating admixtures, a clear formation of AFm phases was found during the first stages of hydration. The acceleration ability has been related to the appearance of these AFm phases through different mechanisms: in the case of lithium salts, the modification of $\mathrm{C} / \mathrm{A}$ ratio by a strong reduction of the aluminium in the solution was critical. In other cases, the structure of the AFm phases allowed to uptake some ions (such as $\mathrm{Zn}^{2+}$ or $\mathrm{Cr}^{3+}$ ) yielding significant amounts of hydrates of very low solubility, which formation would explain the heat evolution and the acceleration of the hydration. 
Also the anions (nitrate or chloride as counterions or even chromate) can be incorporated into the interlayer space of the double layer structure of the AFm phases, giving rise to insoluble and stable compounds. The influence of the $\mathrm{Cl}-\mathrm{AFm}$ and $\mathrm{NO}_{3}$ AFm stability would appear to be important to explain the effect of these counterions: the presence of chloride usually caused the main hydration process to take place later than that of nitrate. Chromate also yielded stable AFm hydrates, causing a slight acceleration of the hydration.

Finally, the addition of $\mathrm{Pb}\left(\mathrm{NO}_{3}\right)_{2}, \mathrm{CuCl}_{2}$ and $\mathrm{Cu}\left(\mathrm{NO}_{3}\right)_{2}$ resulted in a low degree of hydration and experimental data showed a slowdown of the hydration process. For these salts, the role of the cations was determining: $\mathrm{Pb}(\mathrm{II})$ and $\mathrm{Cu}$ (II) form hydroxides of very low solubility products that cover the surface of anhydrous particles preventing them from hydration. A balance between the insolubility of the metal hydroxides (at the alkaline conditions of the calcium aluminate systems also dependant on the low amphoteric character of the compound) and the ability of the formation of AFm phases seems to be very relevant to incline the equilibrium towards the retarding of the hydration or towards the acceleration, respectively.

\section{Acknowledgements}

The authors want to thank Dr. Francisca Puertas and Dr. Mar Alonso for their help with the isothermal calorimetry measurements. This work was fully funded by Fundación Universitaria de Navarra under grant FUNA2013-15108402. M. Pérez-Nicolás thanks the Friends of the University of Navarra, Inc., for a pre-doctoral grant. 


\section{References}

[1] H. Kinoshita, P. Swift, C. Utton, B. Carro-Mateo, G. Marchand, N. Collier, N. Milestone, Corrosion of aluminium metal in OPC- and CAC-based cement matrices, Cem. Concr. Res. 50 (2013) 11-18

[2] I. Navarro-Blasco, A. Duran, R. Sirera, J.M. Fernández, J.I. Alvarez, Solidification/stabilization of toxic metals in calcium aluminate cement matrices, J. Haz. Mat. 260 (2013) 89-103

[3] A. Hidalgo, S. Petit, J.L. Garcia, C. Alonso, C. Andrade, Microstructure of the system calcium aluminate cement-silica fume: application in waste immobilization, in: R. Xu, Z. Gao, J. Chen, W. Yan (Eds.), From Zeolites to Porous MOF Materials, Elsevier, Amsterdam, 2007, pp. 1617-1628

[4] A.P. Luz, V.C. Pandolfelli, Halting the calcium aluminate cement hydration process, Ceram. Int. 37 (8) (2011) 3789-3793

[5] D. Sorrentino, F. Sorrentino, M. George, Mechanisms of hydration of calcium aluminate cements, in: J. Skalny, S. Mindess (Eds.), Materials Science of Concrete IV, The American Ceramic Society, Westerville, 1995, pp. 41-90

[6] H. Justnes, Rapid repair of airfield in cold weather using CAC mortar, in: C.H. Fentiman, K.L. Scrivener, R.J. Mangabhai (Eds.), Proceedings of the Centenary Conference, Calcium Aluminate Cements, HIS BRE Press, Avignon, 2008, pp. 365-373

[7] C. Jantzen, A. Johnson, D. Read, J.A. Stegemann, Cement in waste management, Adv. Cem. Res. 22 (4) (2010) 225-231

[8] B.R. Currell, R. Grzeskowlak, H.G. Midgley, J.R. Parsonage, The acceleration and retardation of set high alumina cement by additives, Cem. Concr. Res. 17 (3) (1987) $420-432$

[9] M. Murat, E.H. Sadok, Role of foreign cation in solution in the hydration kinetics of high alumina cement, in: R.J. Mangabhai (Ed.), Calcium Aluminate Cements, Chapman and Hall, London, 1990, pp. 155-166 
[10] S.A. Rodger, D.D. Double, The chemistry of hydration of high alumina cement in the presence of accelerating and retarding admixtures, Cem. Concr. Res. 14 (1) (1984) $73-82$

[11] N. Ukrainczyk, N. Vrbos, J. Šipušić, Influence of metal chloride salts on calcium aluminate cement hydration, Adv. Cem. Res. 24 (5) (2012) 249-262

[12] A.N. Scian, J.M. Porto López, E. Pereira, High alumina cements. Study of $\mathrm{CaO} \cdot \mathrm{Al}_{2} \mathrm{O}_{4}$ formation stoichiometric mechanism, Cem. Concr. Res. 17 (1987) 198-204

[13] J.M. Rivas Mercury, A.H. De Aza, P. Pena, Synthesis of $\mathrm{CaAl}_{2} \mathrm{O}_{4}$ from powders: Particle size effect, J. Europ. Cer. Soc. 25 (14) (2005) 3269-3279

[14] M.M. Ali, S.K. Argawal, S.K. Handoo, Diffusion studies in formation and sintering of $\mathrm{CaAl}_{2} \mathrm{O}_{4}$ and $\mathrm{BaAl}_{2} \mathrm{O}_{4}$ : a comparative evaluation, Cem. Concr. Res. 27 (7) (1997) 979-982

[15] J.M. Fernández, I. Navarro-Blasco, A. Duran, R. Sirera, J.I. Alvarez. Treatment of toxic metal aqueous solutions: encapsulation in a phosphate-calcium aluminate matrix. $\mathrm{J}$ Environ Manage 140 (2014) 1-13.

[16] N. Gineys, G. Aouad, D. Damidot, Managing trace elements in Portland cementPart I: Interactions between cement paste and heavy metals added during mixing as soluble salts, Cem. Concr. Compos. 32 (2010) 563-570

[17] S. Berger, C. Cau Dit Coumes, P. Le Bescop, D. Damidot, Hydration of calcium sulfoaluminate cement by a $\mathrm{ZnCl}_{2}$ solution: investigation at early age, Cem. Concr. Res. 39 (2009) 1180-1187

[18] J.I. Alvarez, J.M. Fernández, I. Navarro-Blasco, A. Duran, R. Sirera, Microstructural consequences of nanosilica addition on aerial lime binding materials: Influence of different drying conditions, Mater. Charact. 80 (2013) 36-49

[19] B. Pacewska, I. Wilinska, M. Nowacka, Studies on the influence of different fly ashes and Portland cement on early hydration of calcium aluminate cement, J. Therm. Anal. Calorim. 106 (2011) 859-868 
[20] A. Hidalgo, J.L. García, M. Cruz Alonso, L. Fernández, C. Andrade, Microstructure development in mixes of calcium aluminate cement with silica fume or fly ash, J. Therm. Anal. Calorim. 96 (2) (2009) 335-345

[21] R.N. Edmonds, A.J. Majumdar, The hydration of $12 \mathrm{CaO} \cdot 7 \mathrm{Al}_{2} \mathrm{O}_{3}$ at different temperatures, Cem. Concr. Res. 18 (3) (1988) 473-478

[22] C. Gosselin, E. Gallucci, K. Scrivener, Influence of self heating and $\mathrm{Li}_{2} \mathrm{SO}_{4}$ addition on the microstructural development of calcium aluminate cement, Cem. Concr. Res. 40 (10) (2010) 1555-1570

[23] L.G. Baquerizo, T. Matschei, K.L. Scrivener, M. Saeidpour, L. Wadsö, Hydration states of AFm cement phases, Cem. Concr. Res. 73 (2015) 143-157

[24] T. Matschei, B. Lothenbach, F.P. Glasser, The AFm phase in Portland cement, Cem. Concr. Res. 37 (2) (2007) 118-130

[25] F.G. Buttler, L.S.D. Glasser, H.F.W. Taylor, Studies on 4CaO.A12O3.13H2O and the related natural mineral hydrocalumite, J. Am. Ceram. Soc. 42 (1959), 121-126

[26] R.O. Grishchenko, A.L. Emelina, P.Y. Makarov, Thermodynamic properties and thermal behaviour of Friedel's salt, Thermochim. Acta 570 (2013) 74-79

[27] U.A. Birnin-Yauri, F.P. Glasser, Friedel's salt, $\mathrm{Ca}_{2} \mathrm{Al}(\mathrm{OH})_{6}(\mathrm{Cl}, \mathrm{OH}) \cdot 2 \mathrm{H}_{2} \mathrm{O}$ : its solid solutions and their role in chloride binding, Cem. Concr. Res. 28 (12) (1998) 17131723

[28] G. Falzone, M. Balonis, G. Sant, X-AFm stabilization as a mechanism of bypassing conversion phenomena in calcium aluminate cements, Cem. Concr. Res. 72 (2015) 54 68

[29] N. Ukrainczyk, T. Matusinovic, S. Kurajica, B. Zimmermann, J. Sipusic, Dehydration of a layered double hydroxide $-\mathrm{C}_{2} \mathrm{AH}_{8}$, Thermochim. Acta 464 (2007) 715 
[30] J. Szczerba, D. Madej, E. Śnieżek, R. Prorok, The application of DTA and TG methods to investigate the non-crystalline hydration products of $\mathrm{CaAl}_{2} \mathrm{O}_{4}$ and $\mathrm{Ca}_{7} \mathrm{ZrAl}_{6} \mathrm{O}_{18}$ compounds, Thermochim. Acta 567 (2013) 40-45

[31] N. Schmitt, J.-F. Hernandez, V. Lamour, Y. Berthaud, P. Meunier, J. Poirier, Coupling between kinetics of dehydration, physical and mechanical behaviour for high alumina castable, Cem. Concr. Res. 30 (2000) 1597-1607

[32] G. Renaudin, J.-P. Rapin, B. Humbert, M. François, Thermal behaviour of the nitrated AFm phase $\mathrm{Ca}_{4} \mathrm{Al}_{2}(\mathrm{OH})_{12}\left(\mathrm{NO}_{3}\right)_{2} \cdot 4 \mathrm{H}_{2} \mathrm{O}$ and structure determination of the intermediate hydrate $\mathrm{Ca}_{4} \mathrm{Al}_{2}(\mathrm{OH})_{12}\left(\mathrm{NO}_{3}\right)_{2} \cdot 2 \mathrm{H}_{2} \mathrm{O}$, Cem. Concr. Res. 30 (2000) 307-314

[33] A-K. Maier, L. Dezmirean, J. Will, P. Greil, Three-dimensional printing of flashsetting calcium aluminate cement, J. Mater. Sci. 46 (2011) 2947-2954

[34] Y. Chen, Z. Shui, W. Chen, G. Chen, Chloride binding of synthetic $\mathrm{Ca}-\mathrm{Al}-\mathrm{NO}_{3}$ LDHs in hardened cement paste, Constr. Build. Mater. 93 (2015) 1051-1058

[35] E. Sakai, Y. Nikaido, T. Itoh, M. Daimon, Ettringite formation and microstructure of rapid hardening cement, Cem. Concr. Res. 34 (9) (2004) 1669-1673

[36] B. Lothenbach, L. Pelletier-Chaignat, F. Winnefeld, Stability in the system CaO$\mathrm{Al}_{2} \mathrm{O}_{3}-\mathrm{H}_{2} \mathrm{O}$, Cem. Concr. Res. 42 (12) (2012) 1621-1634

[37] T. Matschei, B. Lothenbach, F.P. Glasser, Thermodynamic properties of Portland cement hydrates in the system $\mathrm{CaO}-\mathrm{Al}_{2} \mathrm{O}_{3}-\mathrm{SiO}_{2}-\mathrm{CaSO}_{4}-\mathrm{CaCO}_{3}-\mathrm{H}_{2} \mathrm{O}$, Cem. Concr. Res. 37 (10) (2007) 1379-1410

[38] M.R. Nilforoushan, J.H. Sharp, The effect of additions of alkaline-earth metal chlorides on the setting behaviour of a refractory calcium aluminate cement, Cem. Concr. Res. 25 (7) (1995) 1523-1534

[39] J. Bensted, A discussion of the paper: "Lithium salts as set accelerators for high alumina cements" by T. Matusinović and D. Čurlin, Cem. Concr. Res. 24 (2) (1994) $385-386$ 
[40] S.R. Klaus, J. Neubauer, F. Goetz-Neunhoeffer, Hydration kinetics of $\mathrm{CA}_{2}$ and CA-Investigations performed on a synthetic calcium aluminate cement, Cem. Concr. Res. 43 (2013) 62-69

[41] A. Kindness, A. Macias, F.P. Glasser, Immobilization of chromium in cement matrices, Waste Manage. 14 (1) (1994) 3-11

[42] A.K. Suryavanshi, J.D. Scantlebury, S.B. Lyon, Mechanism of Friedel's salt formation in cements rich in tri-calcium aluminate, Cem. Concr. Res. 26 (5) (1996) 717 727

[43] G. Laforest, J. Duchesne, Immobilization of chromium (VI) evaluated by binding isotherms for ground granulated blast furnace slag and ordinary Portland cement, Cem. Concr. Res. 35 (12) (2005) 2322-2332

[44] I. Moulin, J. Rosea, W. Stone, J.-Y. Bottero, F. Mosnier, C. Haelmel, Lead, zinc and chromium (III) and (VI) speciation in hydrated cement phases, in: G.R. Woolley, J.J.J.M. Goumans, P.J. Wainwright (Eds.), Waste Materials in Construction, Elsevier Science Ltd., Amsterdam, 2000, pp. 269-280

[45] O. Yamaguchi, M. Ida, Y. Uchiyama, S. Hanehara, A method for the determination of total Cr(VI) in cement, J. Eur. Ceram. Soc. 26 (4-5) (2006) 785-790

[46] J.W. Boclair, P.S. Braterman, Layered double hydroxide stability. 1. Relative stabilities of layered double hydroxides and their simple counterparts, Chem. Mater. 11 (2) (1999) 298-302

[47] Q. Liu, Y. Li, J. Zhang, Y. Chi, X. Ruan, J. Liu, G. Qian, Effective removal of zinc from aqueous solution by hydrocalumite, Chem. Eng. J. 175 (2011) 33-38

[48] I. Fernández-Olmo, E. Chacon, A. Irabien, Influence of lead, zinc, iron (III) and chromium (III) oxides on the setting time and strength development of Portland cement, Cem. Concr. Res. 31 (8) (2001) 1213-1219

[49] M.A.C. Gollmann, M.M. da Silva, A.B. Masuero, J.H.Z. dos Santos, Stabilization and solidification of $\mathrm{Pb}$ in cement matrices, J. Haz. Mater. 179 (1-3) (2010) 507-514 
Table 1. Mass loss percentages from TG analyses of the control samples with different $\mathrm{w} / \mathrm{c}$ ratios after $48 \mathrm{~h}$.

\begin{tabular}{lccccccc}
\hline $\begin{array}{c}\text { Control } \\
\text { samples }\end{array}$ & $25-100^{\circ} \mathrm{C}$ & $100-200^{\circ} \mathrm{C}$ & $200-340^{\circ} \mathrm{C}$ & $340-550^{\circ} \mathrm{C}$ & $550-1000^{\circ} \mathrm{C}$ & $\begin{array}{c}\text { Weight loss } \\
25-550^{\circ} \mathrm{C}\end{array}$ & $\begin{array}{c}\text { Total weight loss } \\
25-1000^{\circ} \mathrm{C}\end{array}$ \\
\hline w/c 0.40 & 1.15 & 2.17 & 1.64 & 1.13 & 1.75 & 6.09 & 7.84 \\
w/c 0.55 & 1.32 & 3.02 & 2.48 & 1.37 & 2.32 & 8.19 & 10.51 \\
w/c 0.70 & 1.56 & 2.89 & 2.21 & 1.39 & 2.78 & 8.05 & 10.83 \\
w/c 1.58 & 2.72 & 3.88 & 3.64 & 1.91 & 2.79 & 12.15 & 14.94 \\
\hline
\end{tabular}

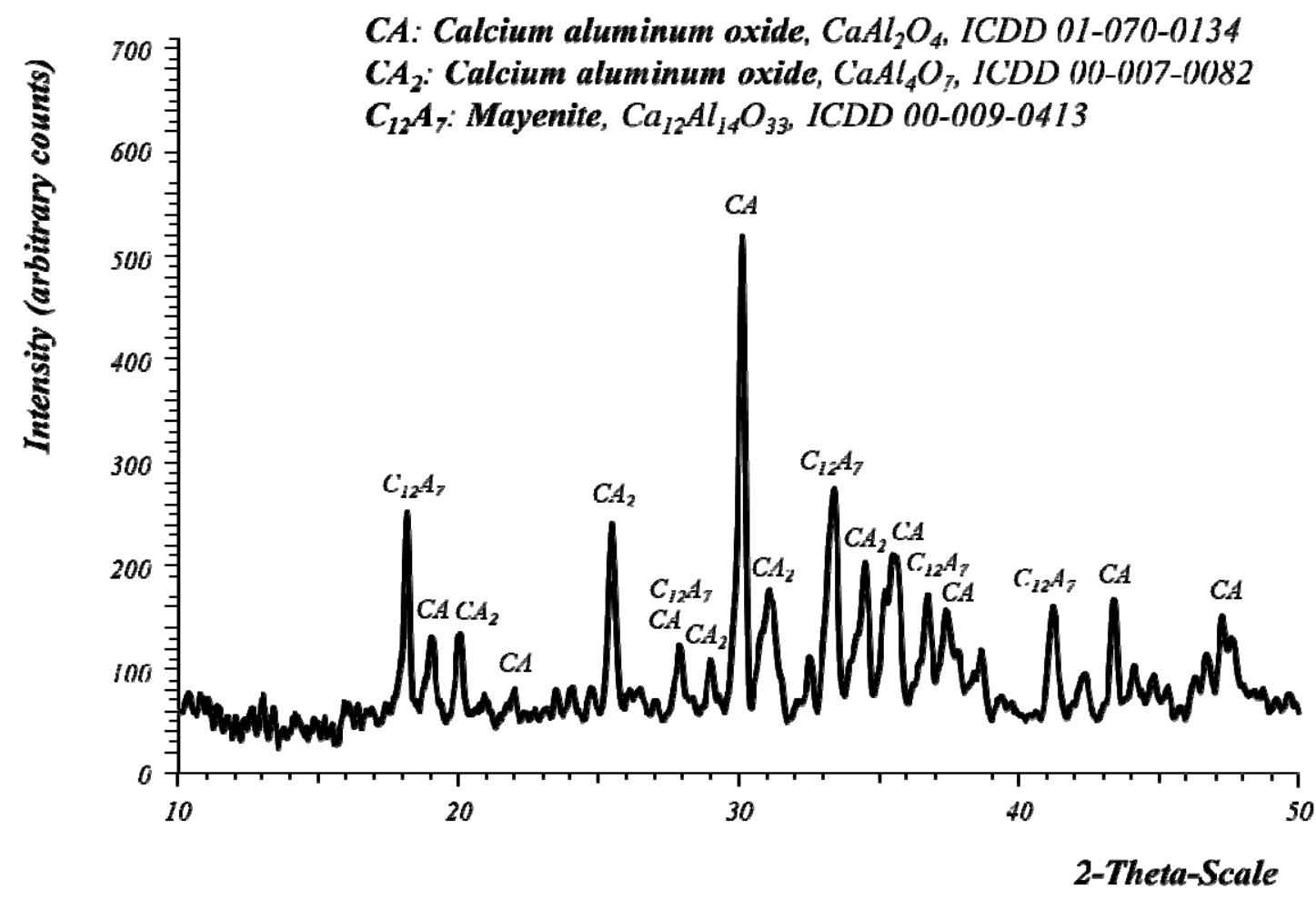

Figure 1. XRD pattern of the raw calcium monoaluminate phase, growing together with minor amounts of $\mathrm{CA}_{2}$ and $\mathrm{C}_{12} \mathrm{~A}_{7}$. 


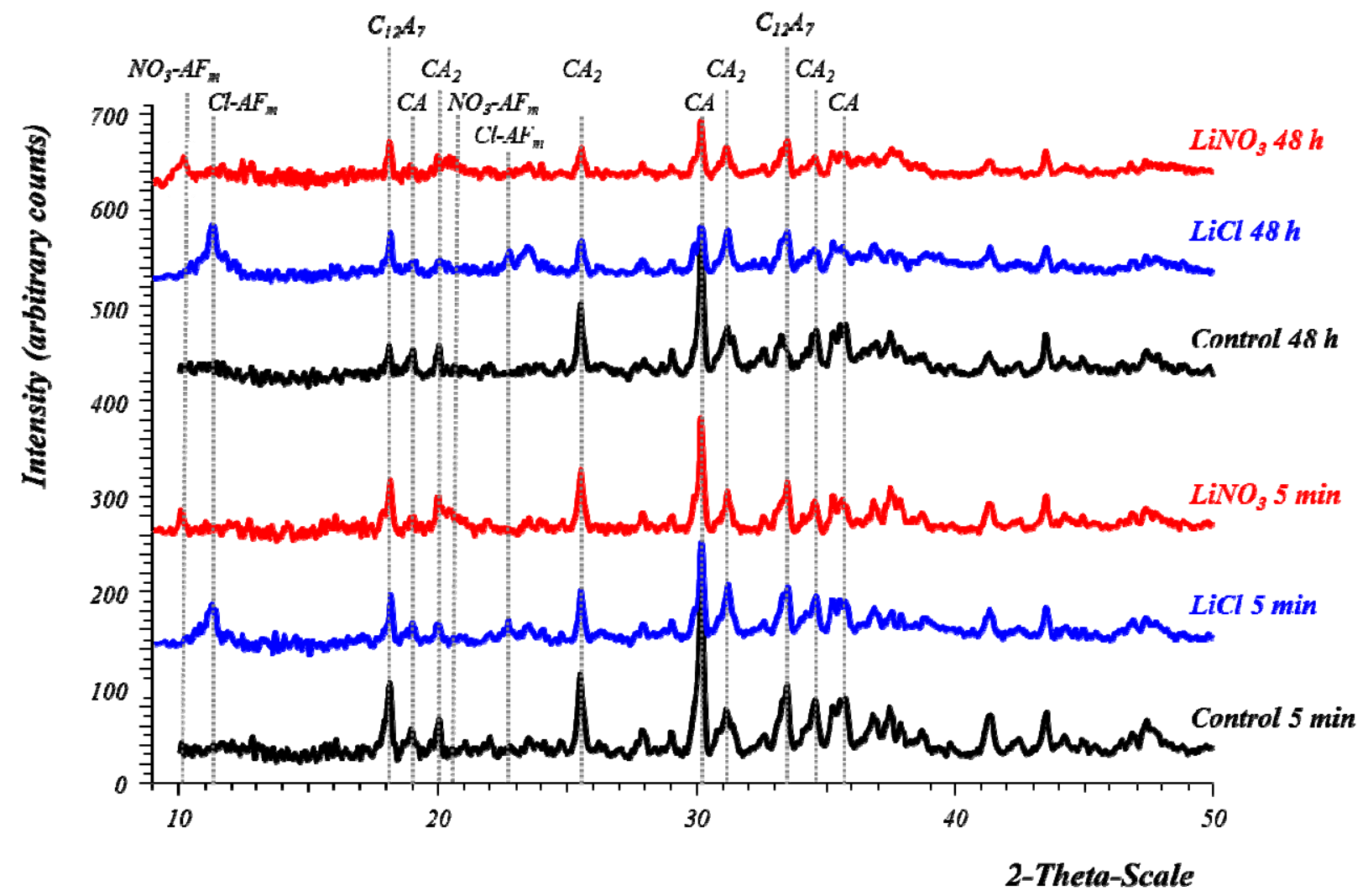

Figure 2. XRD patterns of control, $\mathrm{LiCl}$ and $\mathrm{LiNO}_{3}$ samples after $5 \mathrm{~min}$ and $48 \mathrm{~h}$ of hydration. 

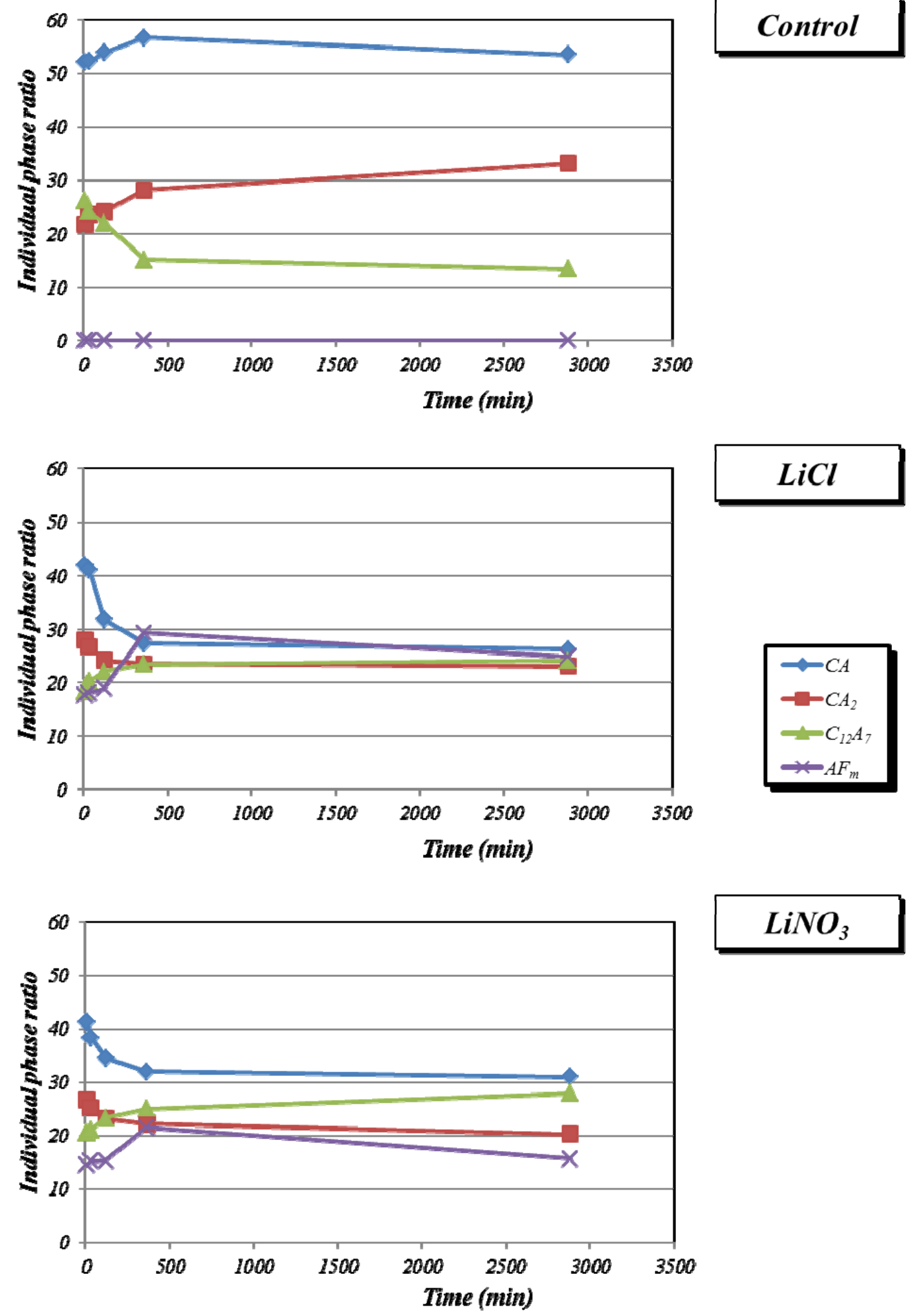

\section{$\mathrm{LiNO}_{3}$}

Figure 3. XRD results of control, $\mathrm{LiCl}$ and $\mathrm{LiNO}_{3}$ samples: semi-quantitative estimation of the phases. 

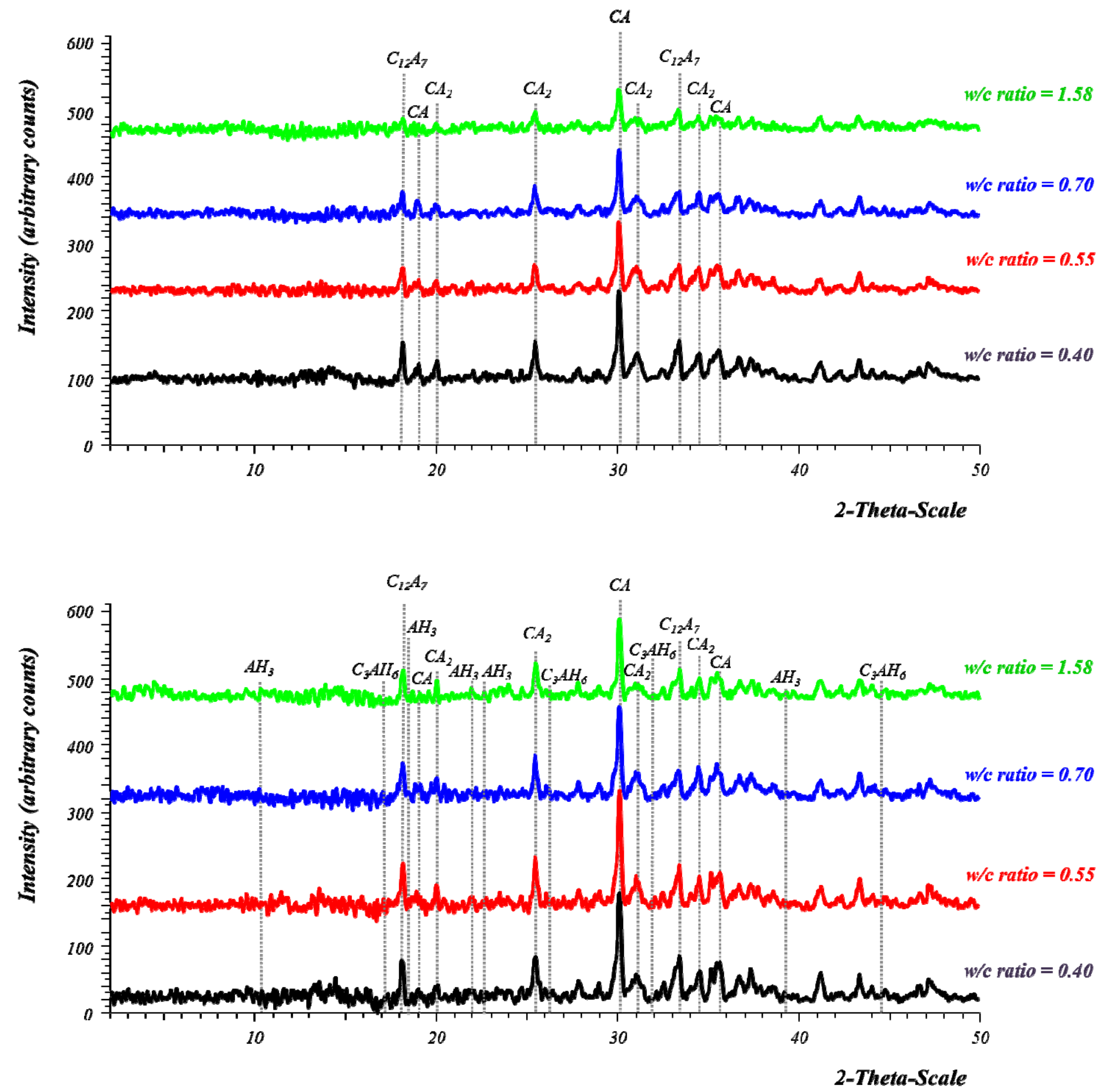

Figure 4. XRD patterns of control samples with different water/calcium aluminate ratios. Top patterns, after $5 \mathrm{~min}$; bottom patterns, after 48 hours. 


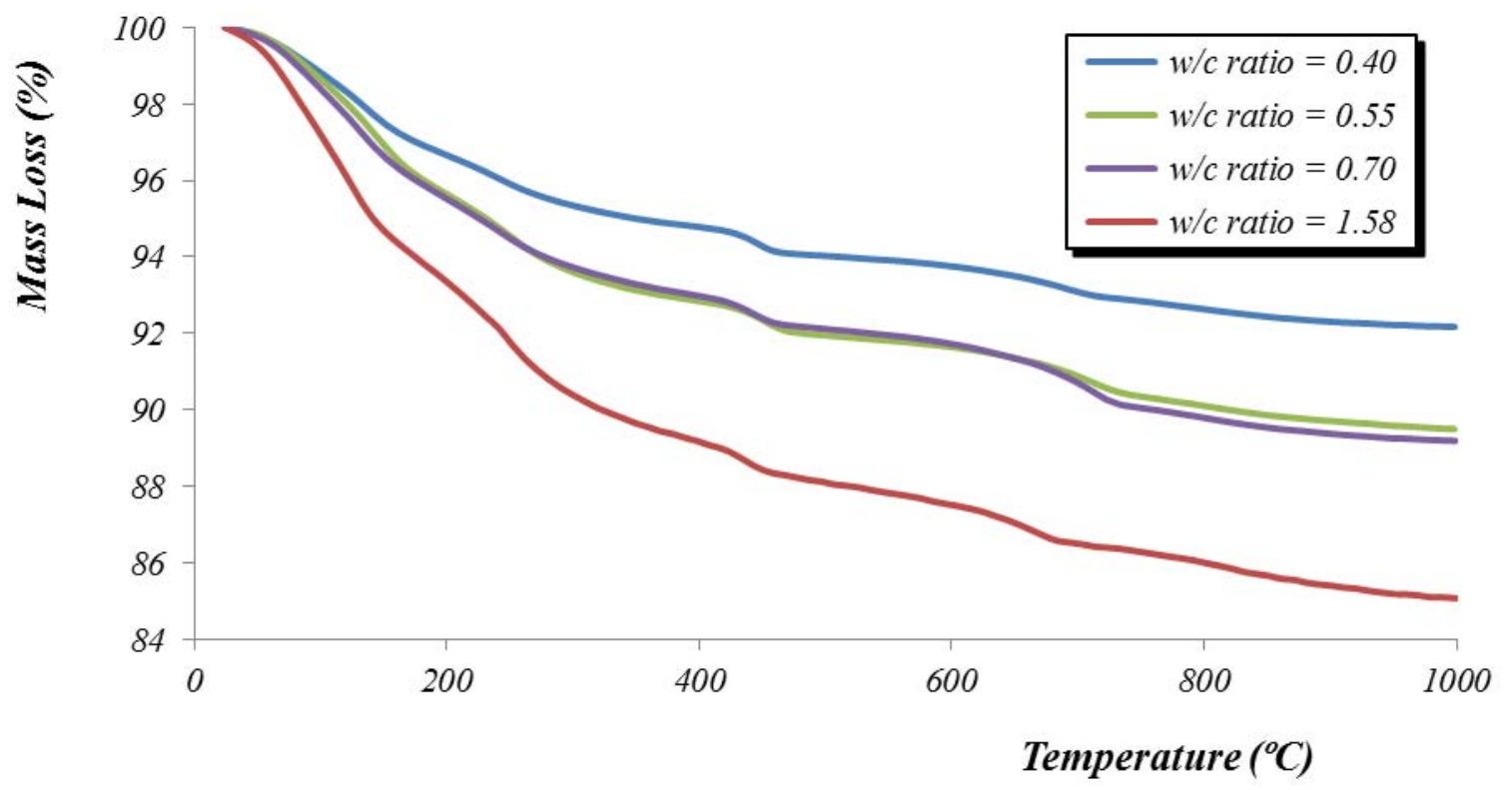

Figure 5. TG curves of control samples with different w/c ratios after $48 \mathrm{~h}$.

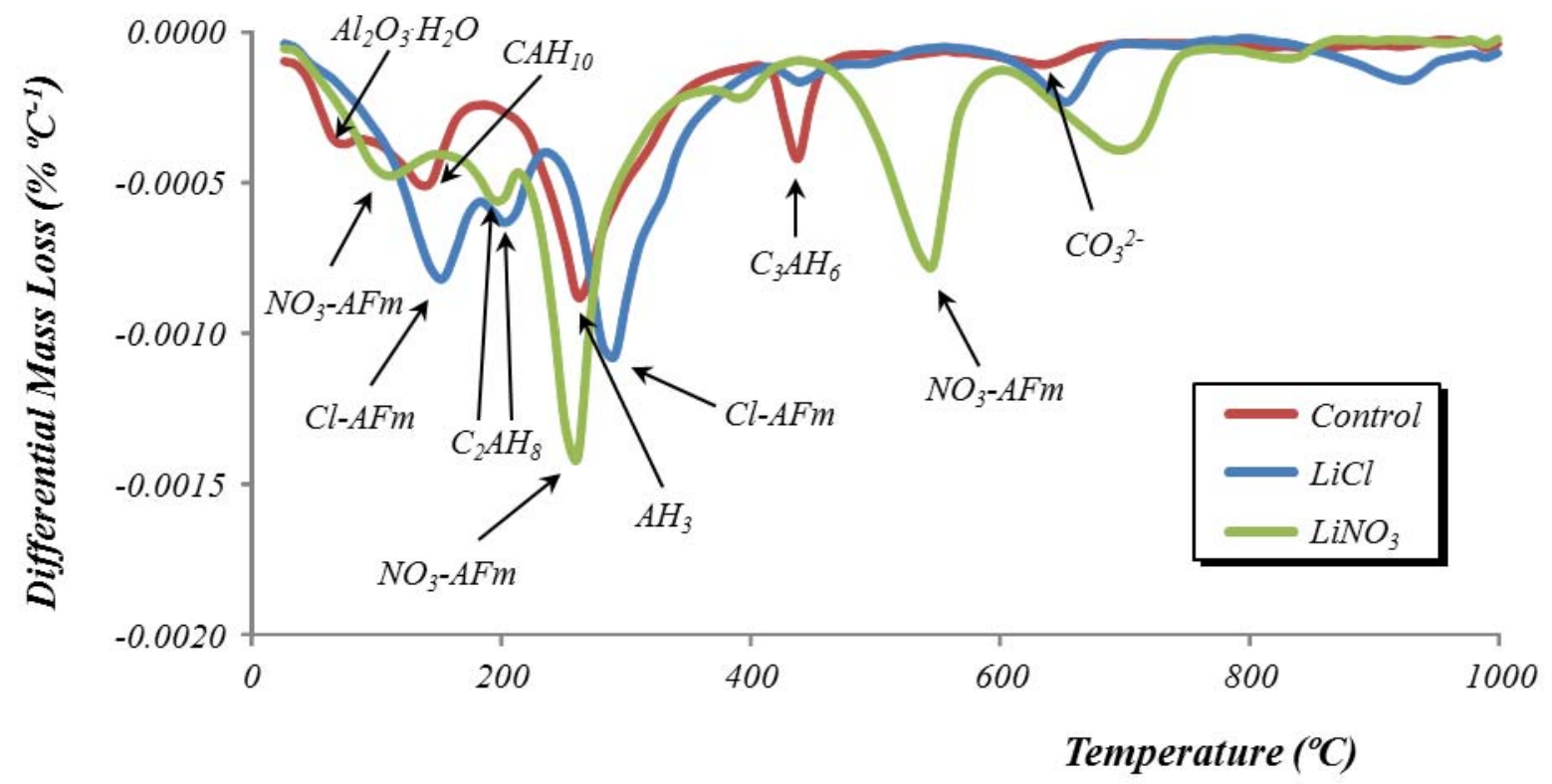

Figure 6. DTG curves of samples with lithium salts after $48 \mathrm{~h}$. Control sample is also shown for comparison purposes. 


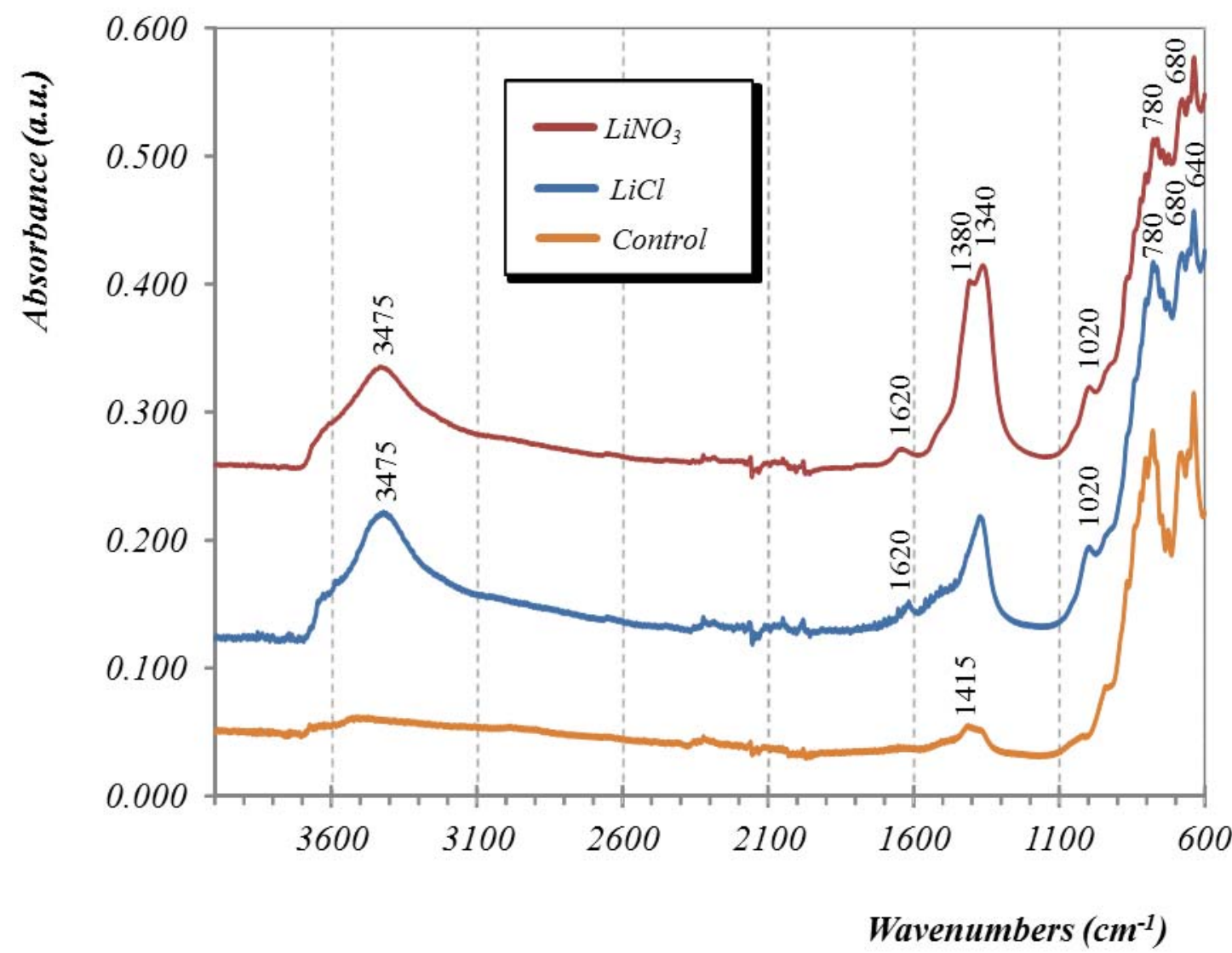

Figure 7. FTIR spectra of control and Li salts-treated samples after 48 hours. 


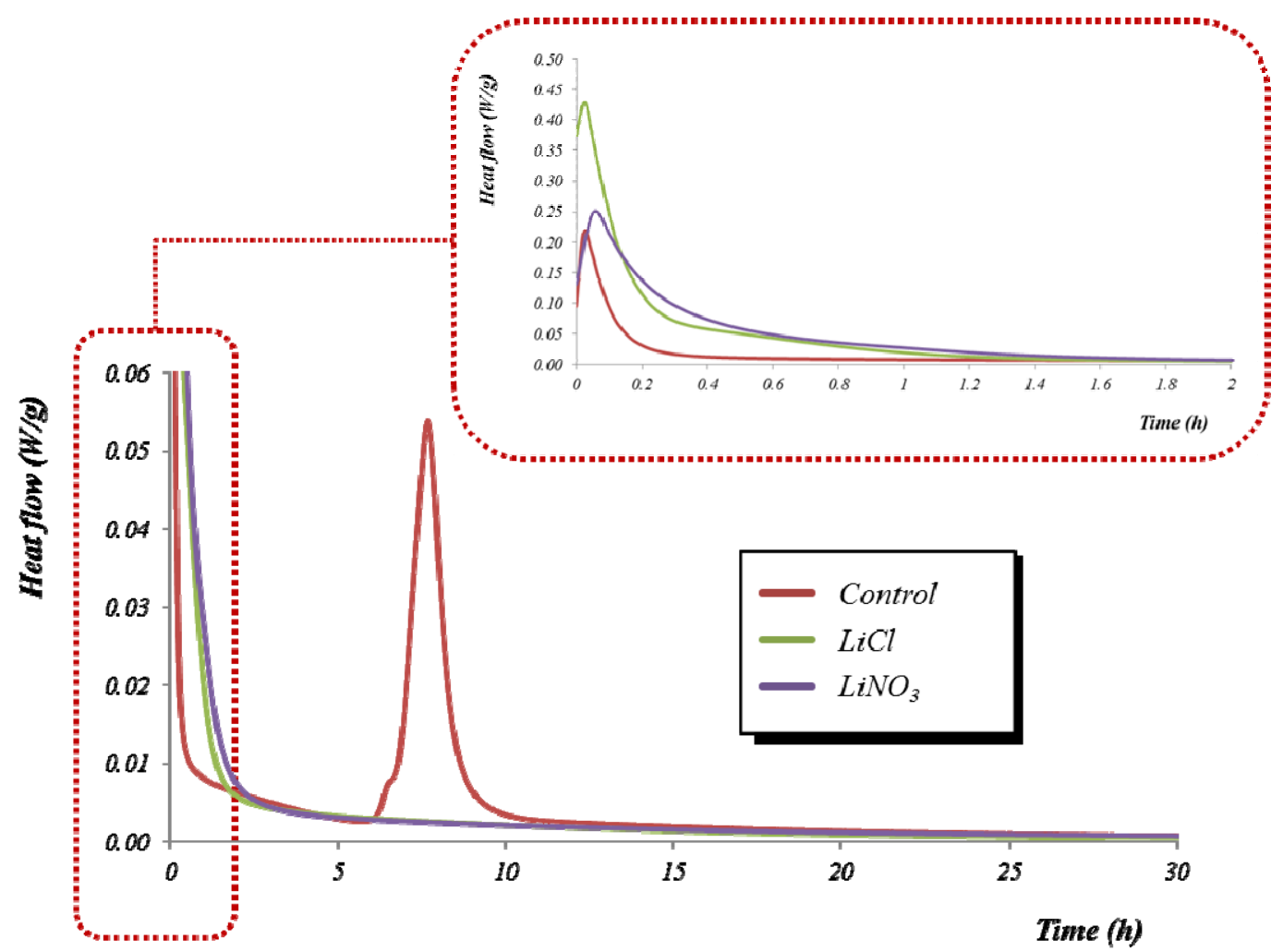

Figure 8. Heat flow curves of control, $\mathrm{LiCl}$ and $\mathrm{LiNO}_{3}$ samples.

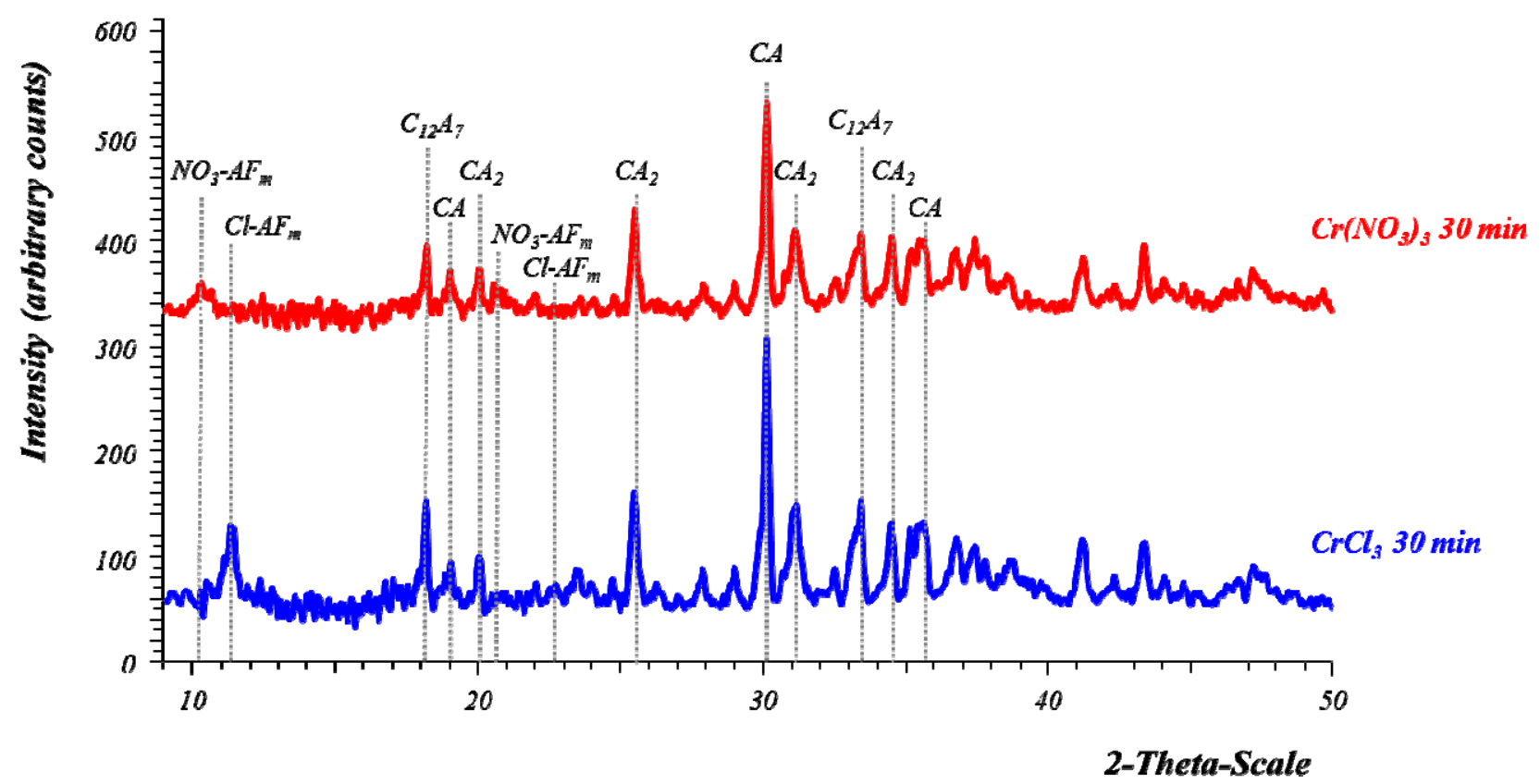

Figure 9. $\mathrm{XRD}$ patterns of $\mathrm{CrCl}_{3}$ and $\mathrm{Cr}\left(\mathrm{NO}_{3}\right)_{3}$ samples (30 min of hydration). 


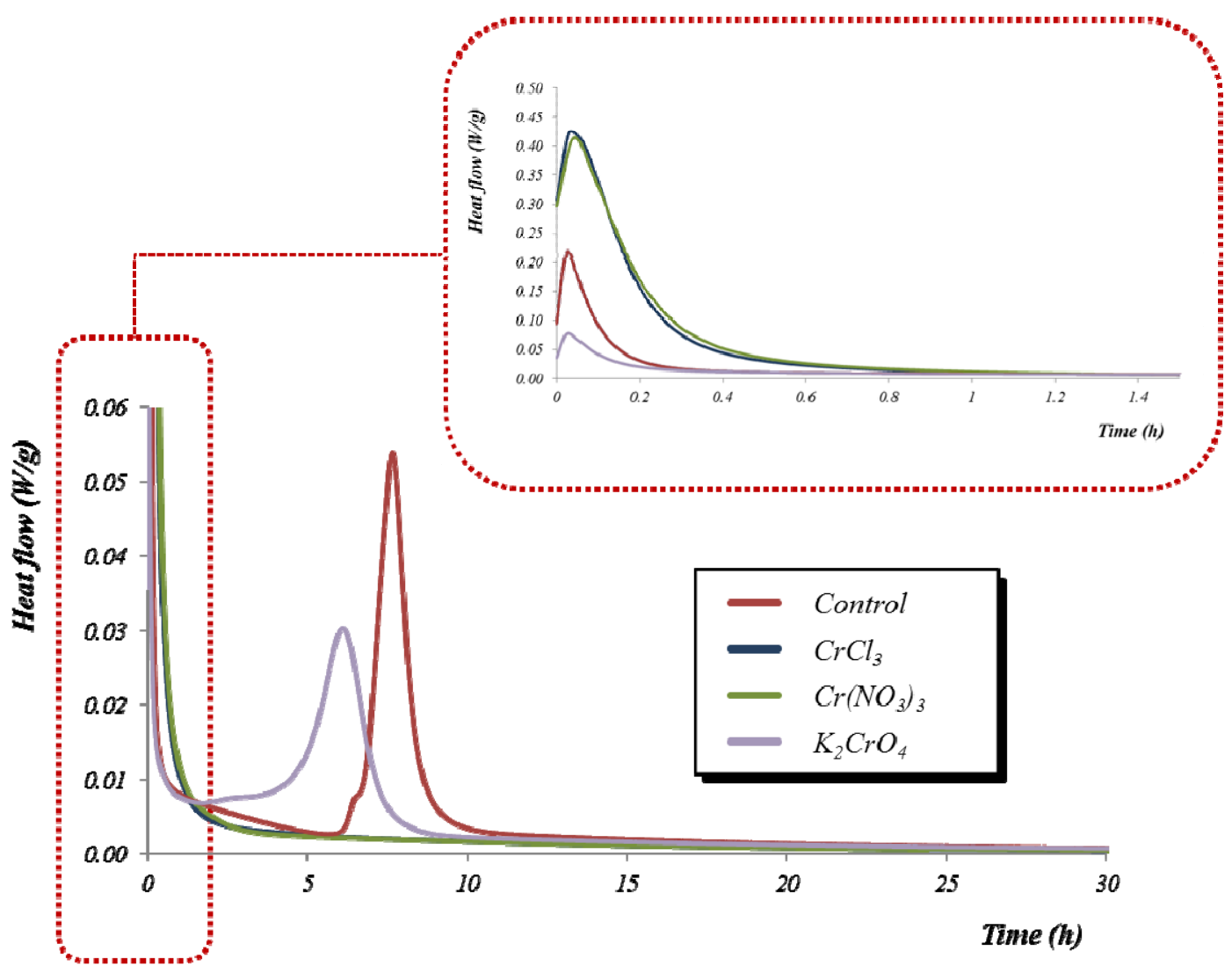

Figure 10. Heat flow curves of control, $\mathrm{CrCl}_{3}, \mathrm{Cr}\left(\mathrm{NO}_{3}\right)_{3}$ and $\mathrm{K}_{2} \mathrm{CrO}_{4}$ samples.

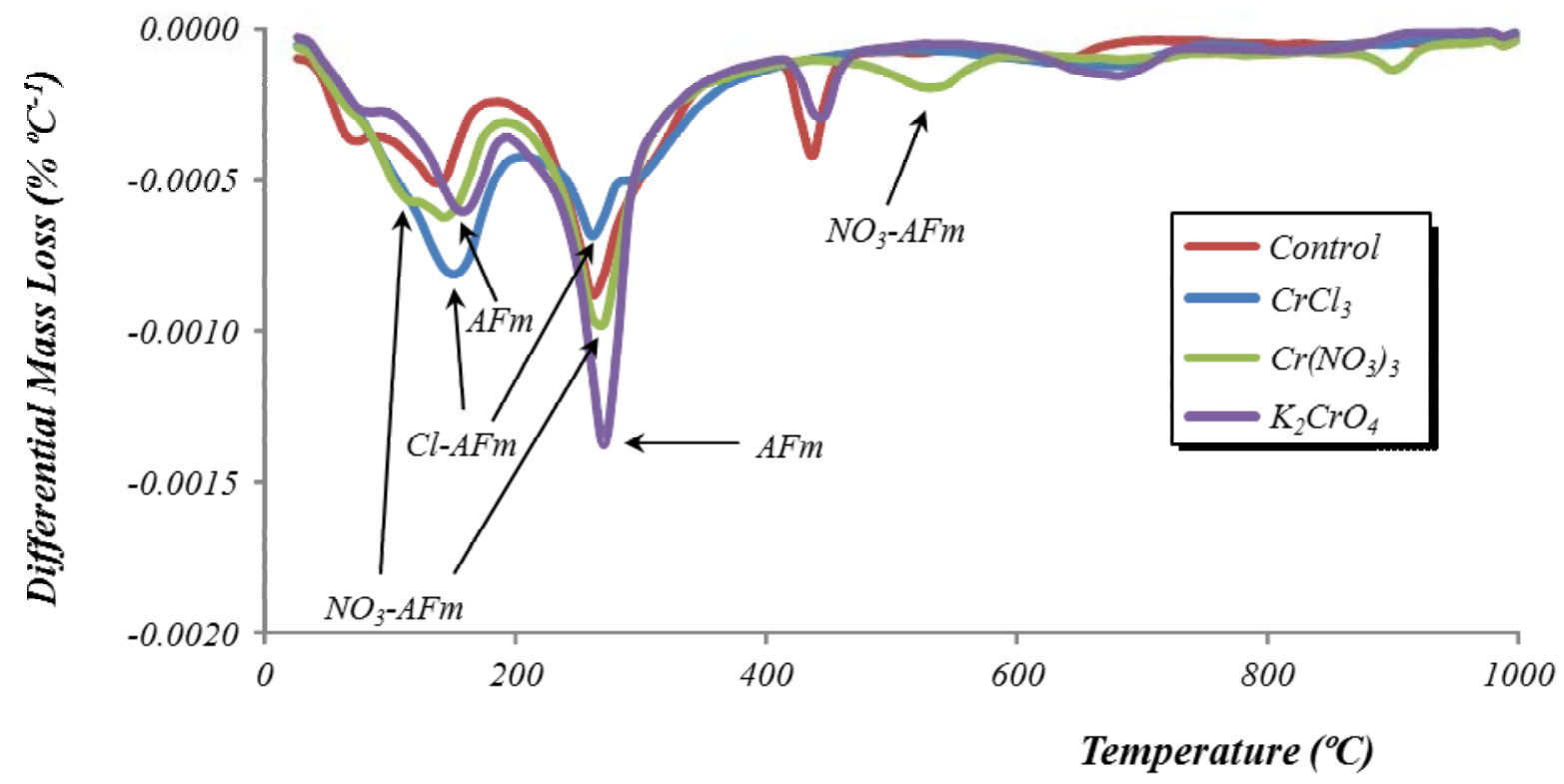

Figure 11. DTG curves of samples with chromium salts after $48 \mathrm{~h}$. Control samples is also shown for comparative purposes. 


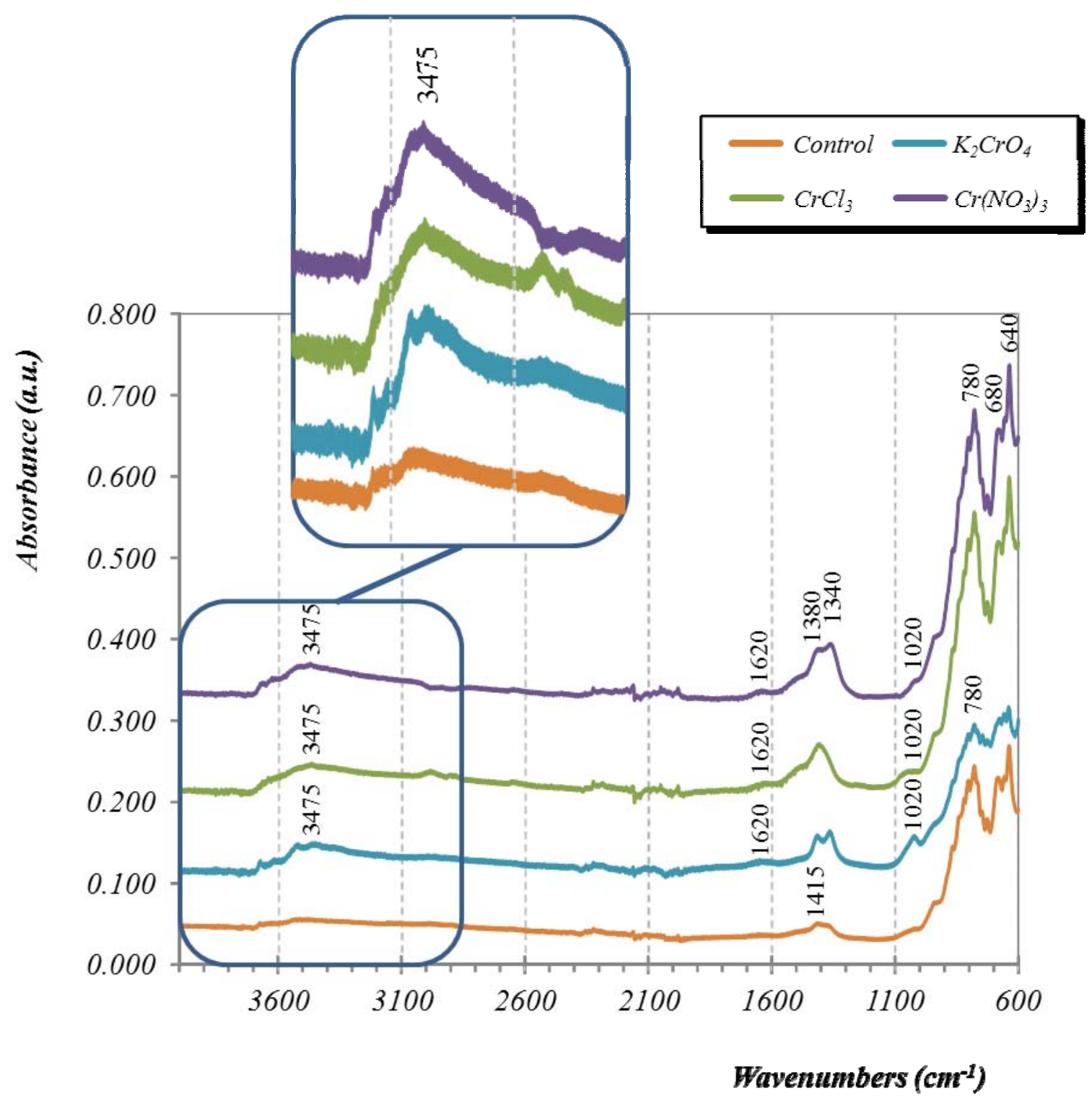

Figure 12. FTIR spectra of the control and chromium-treated samples after 48 hours. 


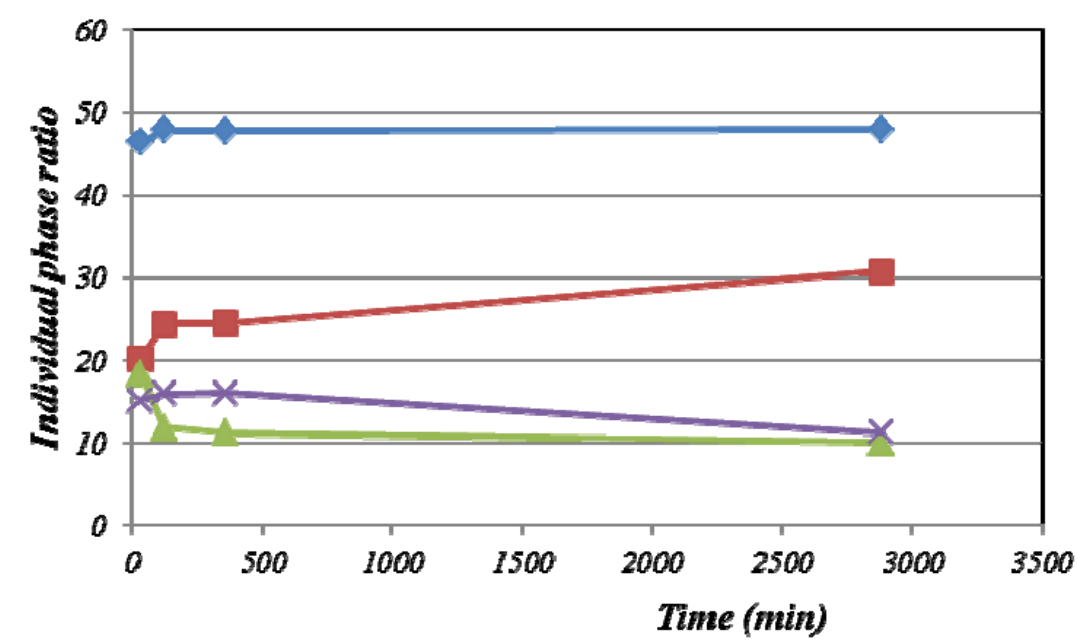

\section{$\mathrm{CrCl}_{3}$}

Time (min)

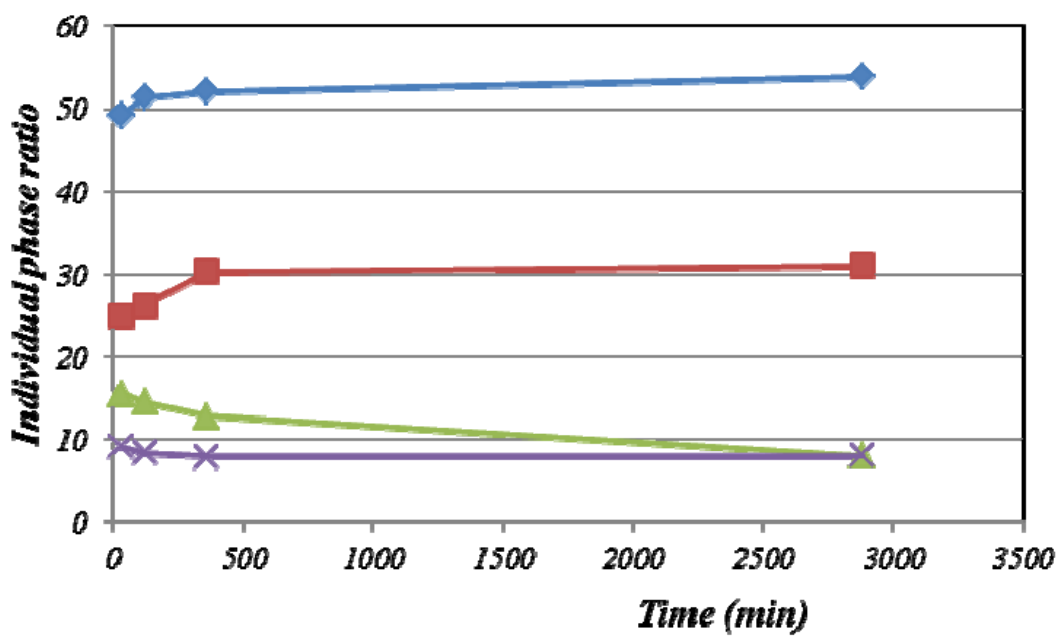

\section{$\mathrm{Cr}\left(\mathrm{NO}_{3}\right)_{3}$}

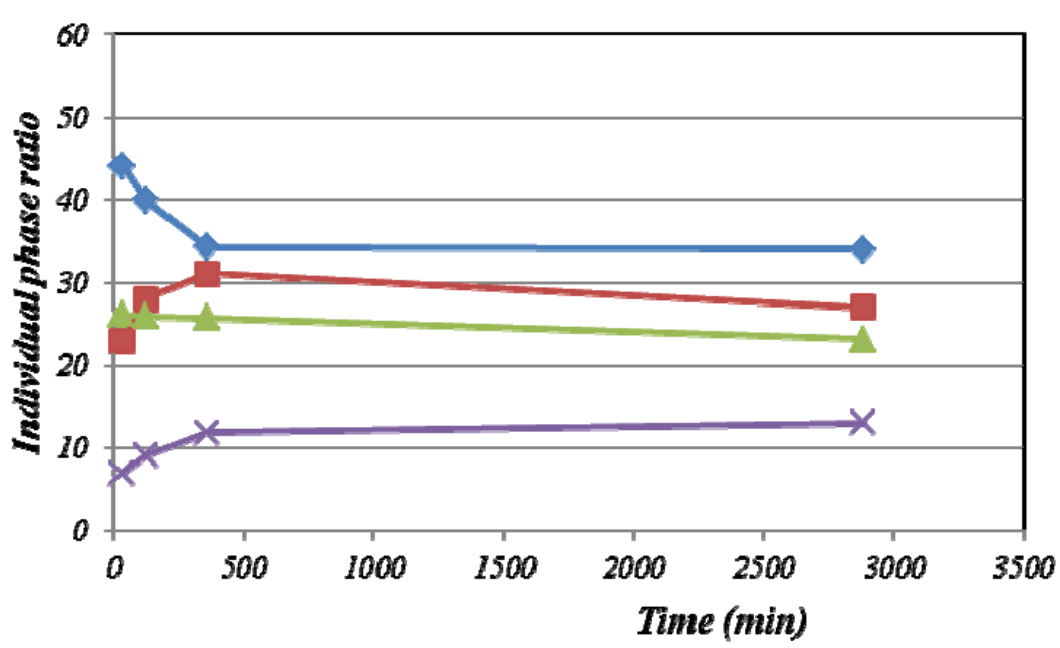

$\mathrm{K}_{2} \mathrm{CrO}_{4}$

Figure 13. Phase assemblage from $\mathrm{XRD}$ results of $\mathrm{CrCl}_{3}, \mathrm{Cr}\left(\mathrm{NO}_{3}\right)_{3}$ and $\mathrm{K}_{2} \mathrm{CrO}_{4}$ samples 

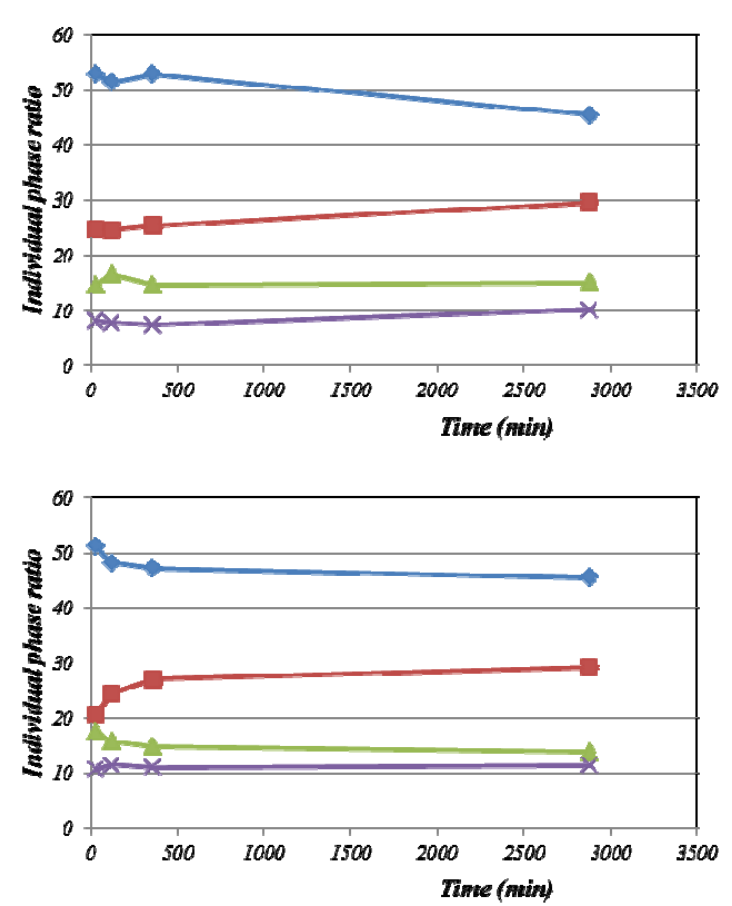

$\mathrm{Zn}\left(\mathrm{NO}_{3}\right)_{2}$

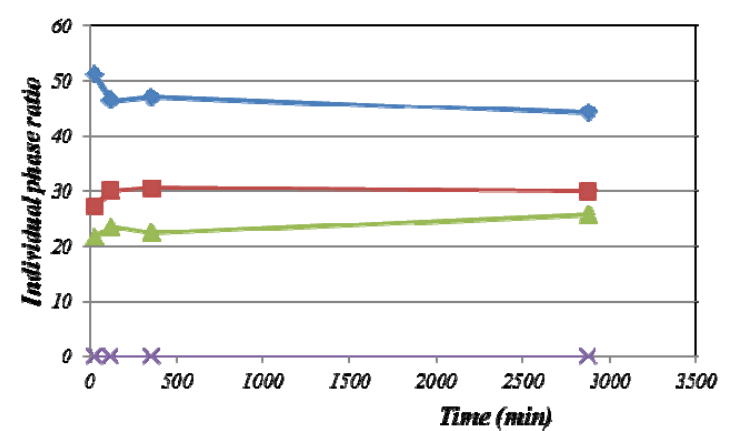

$\mathrm{Pb}\left(\mathrm{NO}_{3}\right)_{2}$

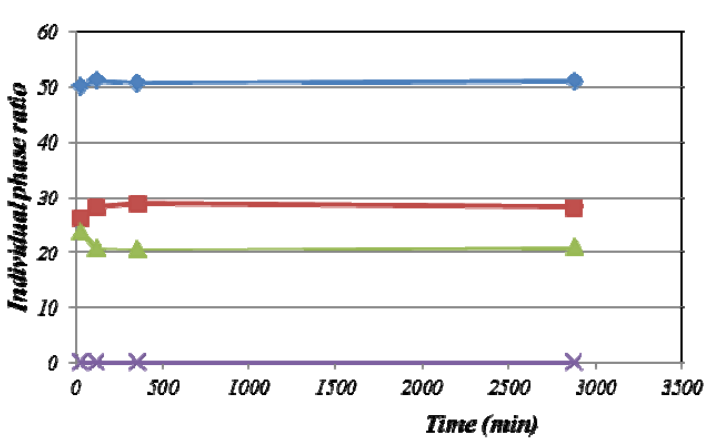

$\mathrm{CuCl}_{2}$

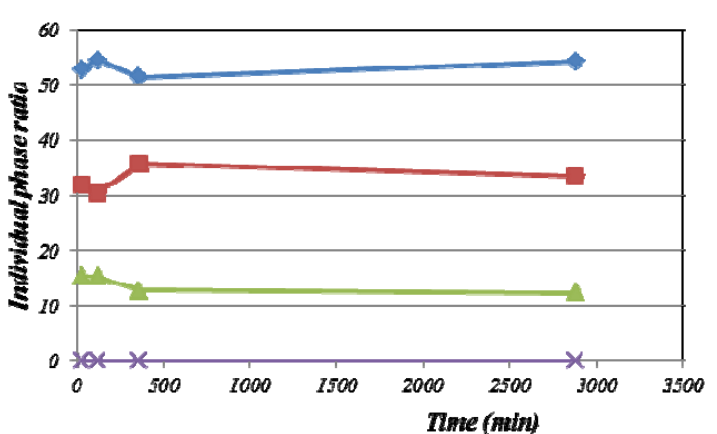

$\mathrm{Cu}\left(\mathrm{NO}_{3}\right)_{2}$

Figure 14. Results from $\mathrm{XRD}$ analysis of samples with $\mathrm{ZnCl}_{2}, \mathrm{Zn}\left(\mathrm{NO}_{3}\right)_{2}, \mathrm{~Pb}\left(\mathrm{NO}_{3}\right)_{2}$, $\mathrm{CuCl}_{2}$ and $\mathrm{Cu}\left(\mathrm{NO}_{3}\right)_{2}$ 


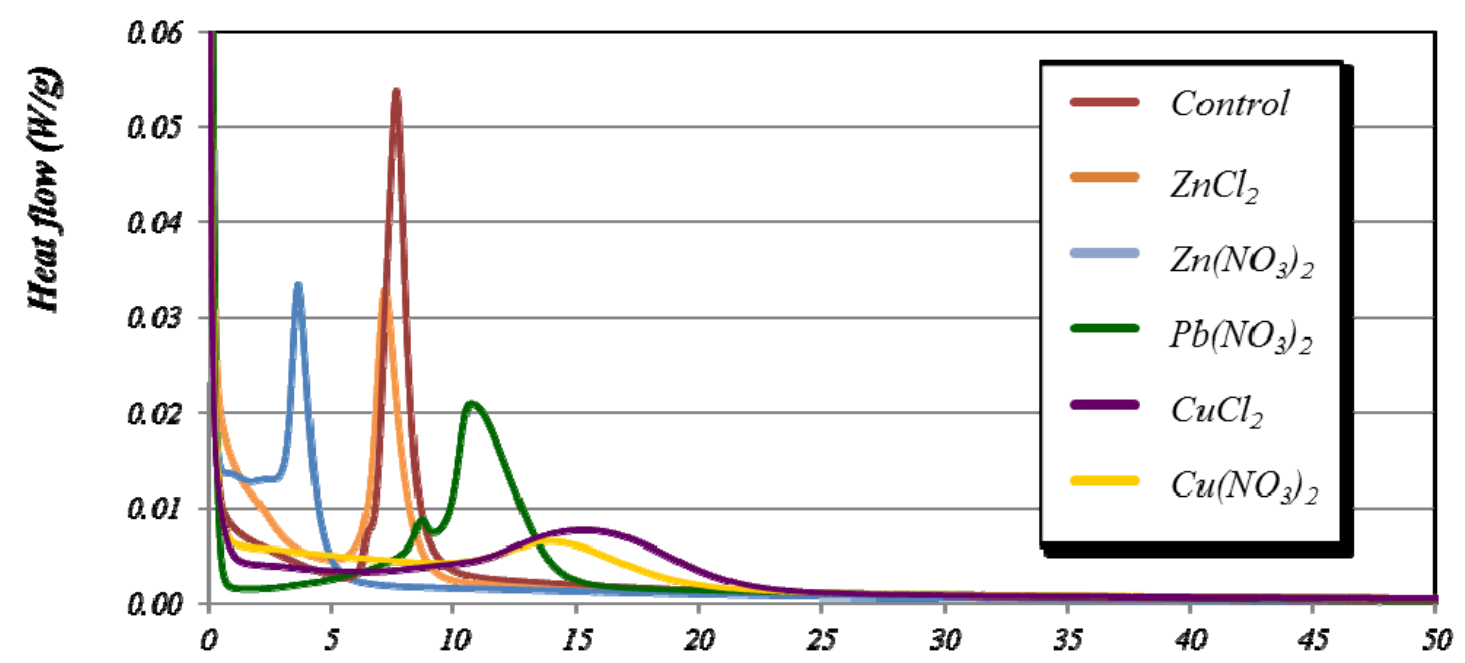

Time (h)

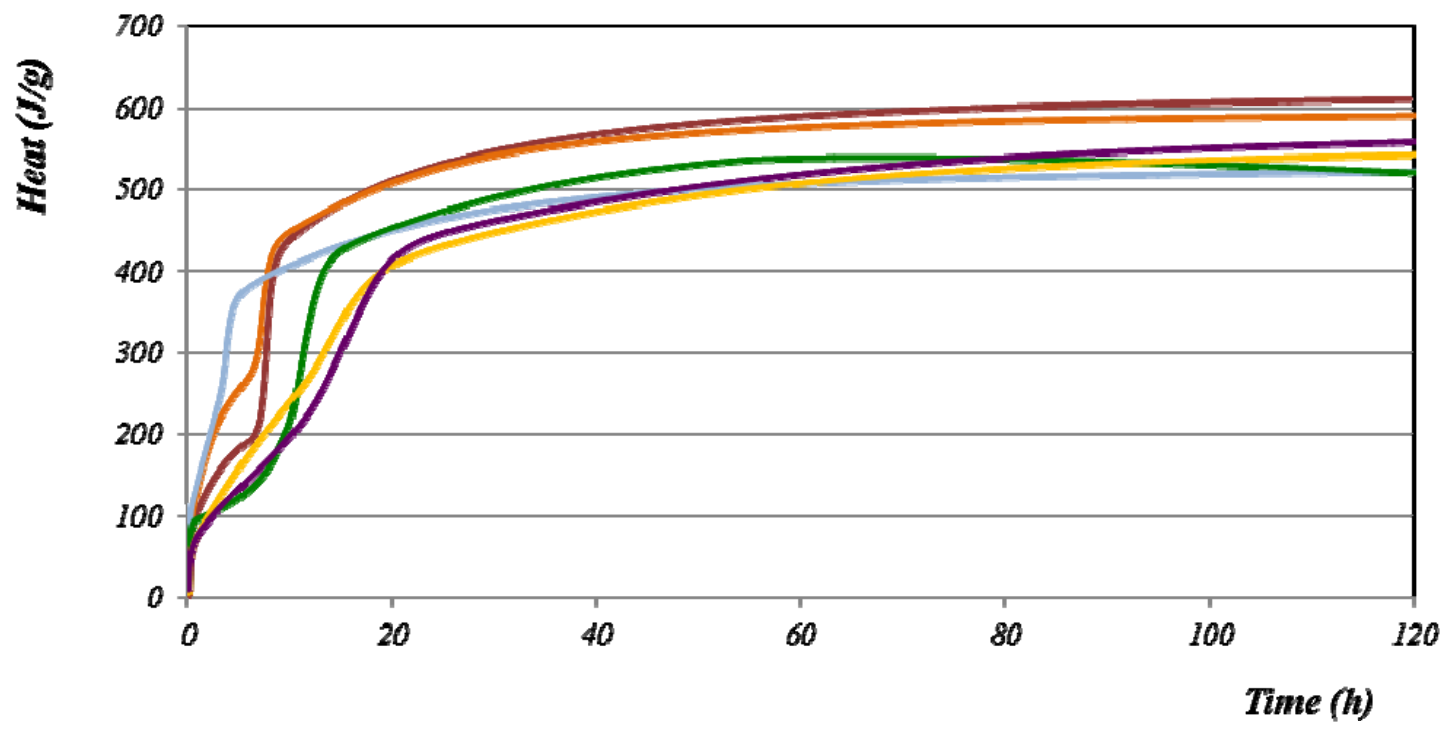

Figure 15. Heat flow (top) and cumulative heat curves (bottom) of control, $\mathrm{ZnCl}_{2}$, $\mathrm{Zn}\left(\mathrm{NO}_{3}\right)_{2}, \mathrm{~Pb}\left(\mathrm{NO}_{3}\right)_{2}, \mathrm{CuCl}_{2}$ and $\mathrm{Cu}\left(\mathrm{NO}_{3}\right)_{2}$ samples. 


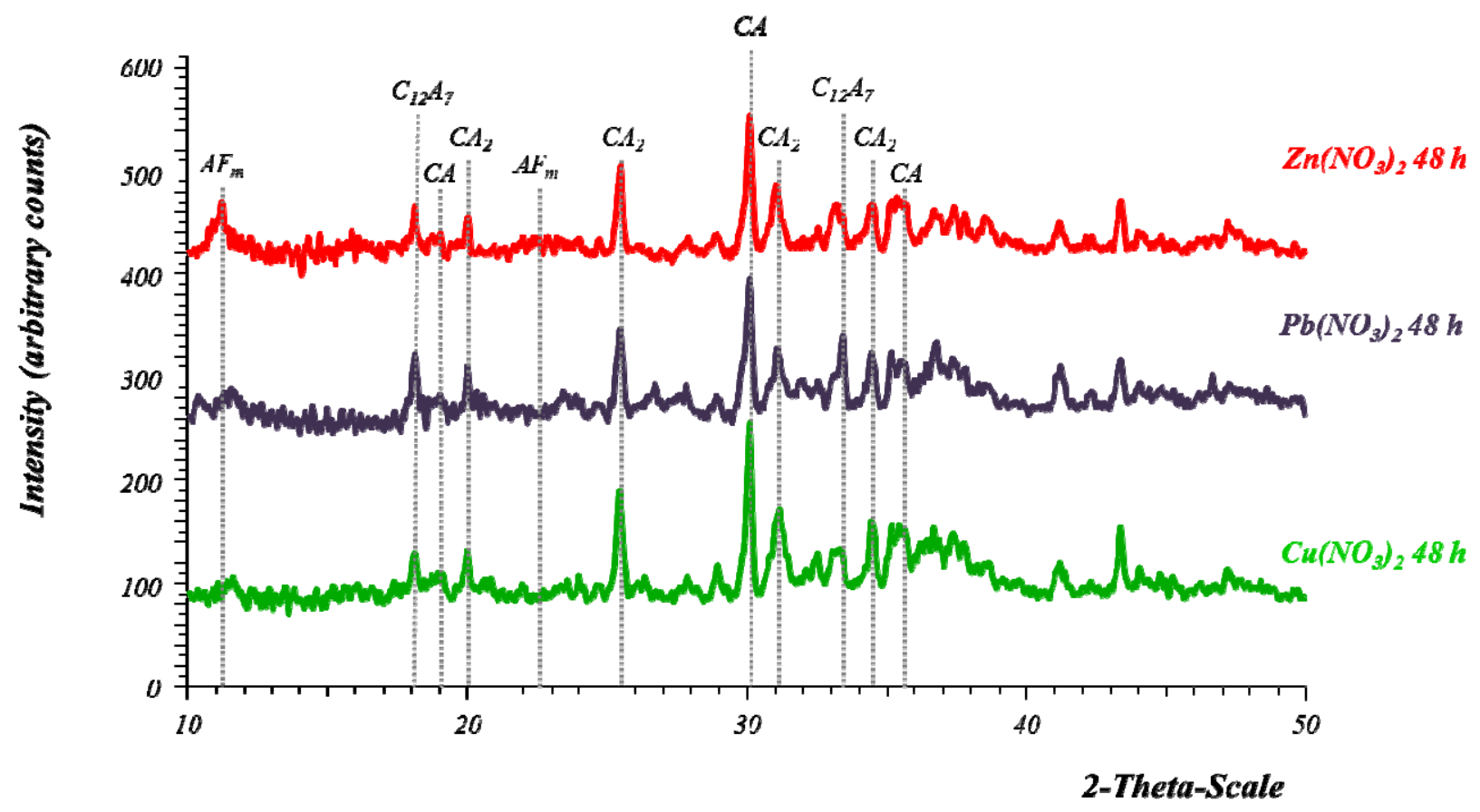

Figure 16. $\mathrm{XRD}$ patterns of $\mathrm{Zn}\left(\mathrm{NO}_{3}\right)_{2}, \mathrm{~Pb}\left(\mathrm{NO}_{3}\right)_{2}$ and $\mathrm{Cu}\left(\mathrm{NO}_{3}\right)_{2}$ samples (stage of hydration: $48 \mathrm{~h}$ ).

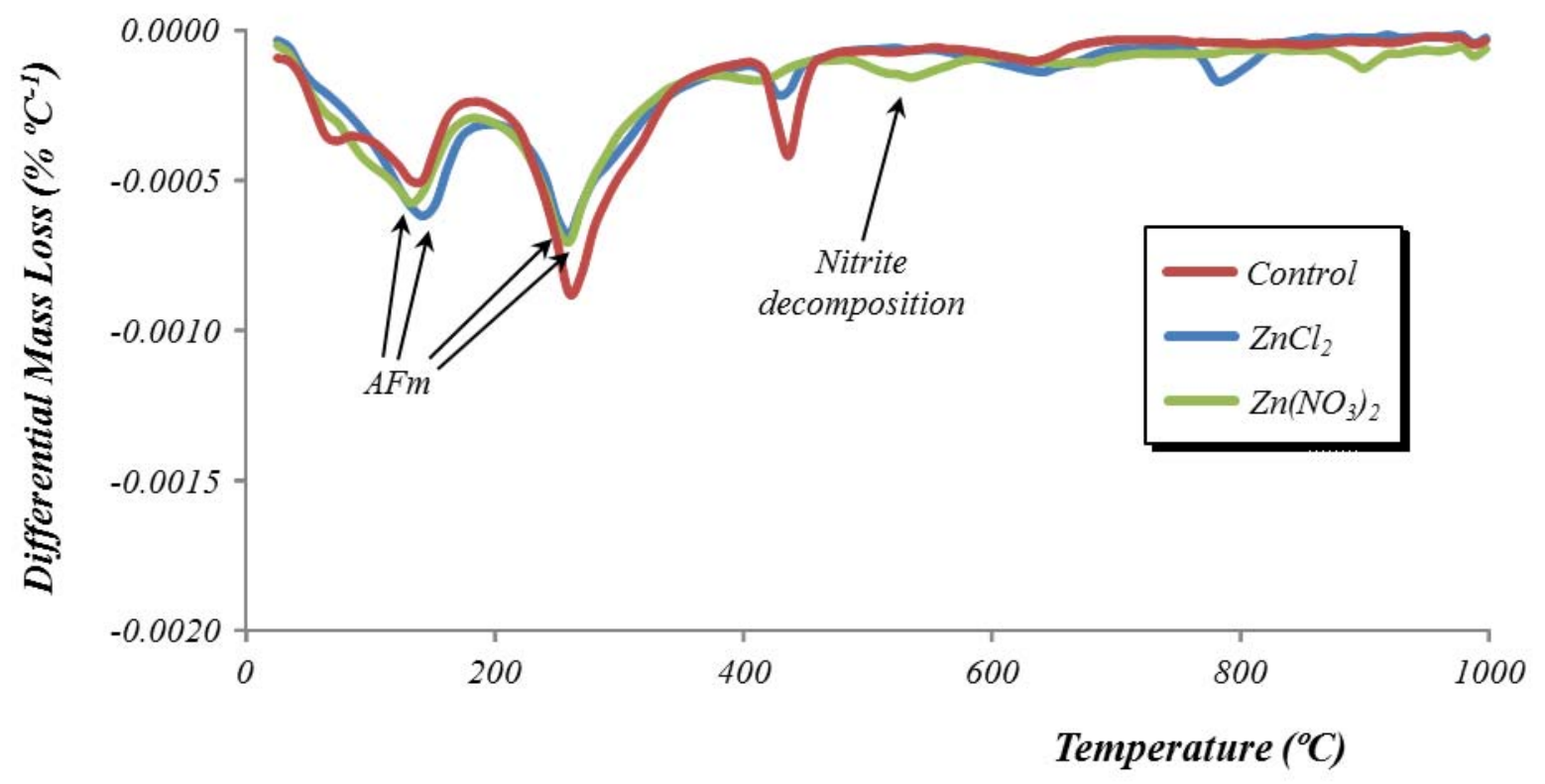

Figure 17. DTG curves of zinc-containing samples (stage of hydration: $48 \mathrm{~h}$ ). Control sample is also shown for comparative purposes. 


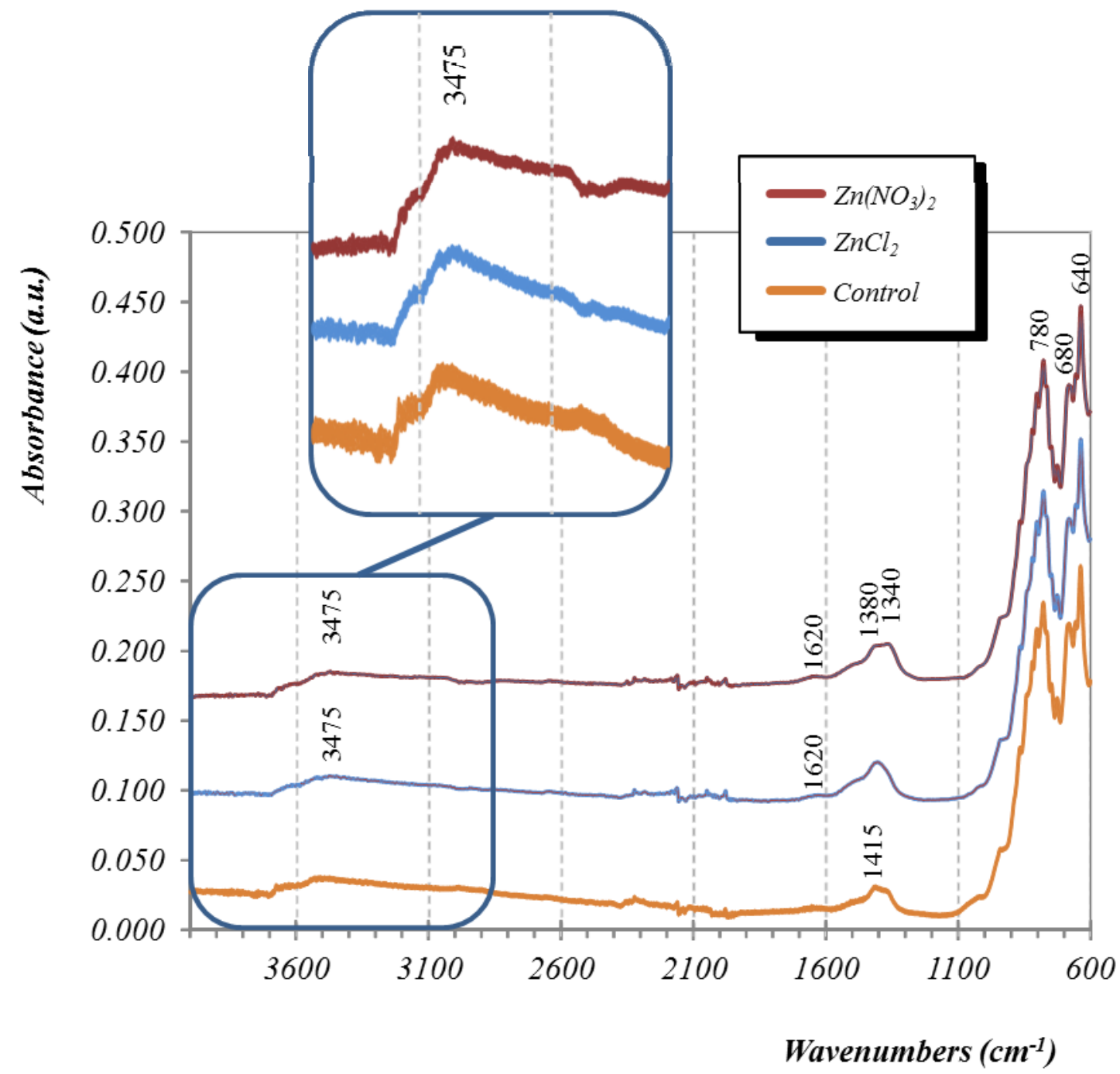

Figure 18. FTIR spectra of Zn-bearing samples after 48 hours vs control sample. 


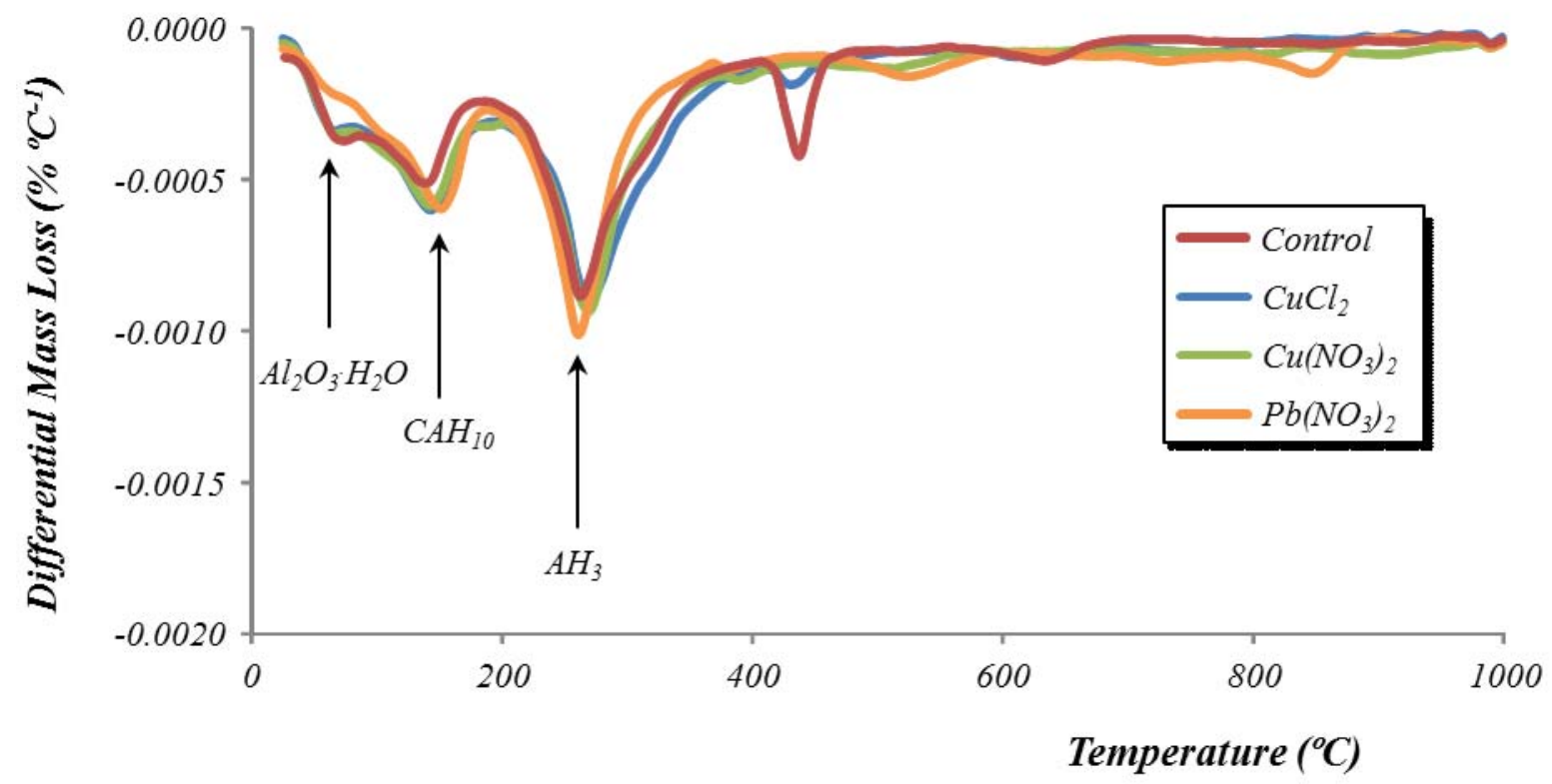

Figure 19. $\mathrm{DTG}$ curves after $48 \mathrm{~h}$ of samples with $\mathrm{Pb}\left(\mathrm{NO}_{3}\right)_{2}, \mathrm{Cu}\left(\mathrm{NO}_{3}\right)_{2}$ and $\mathrm{CuCl}_{2}$. Control sample is also shown for comparative purposes. 


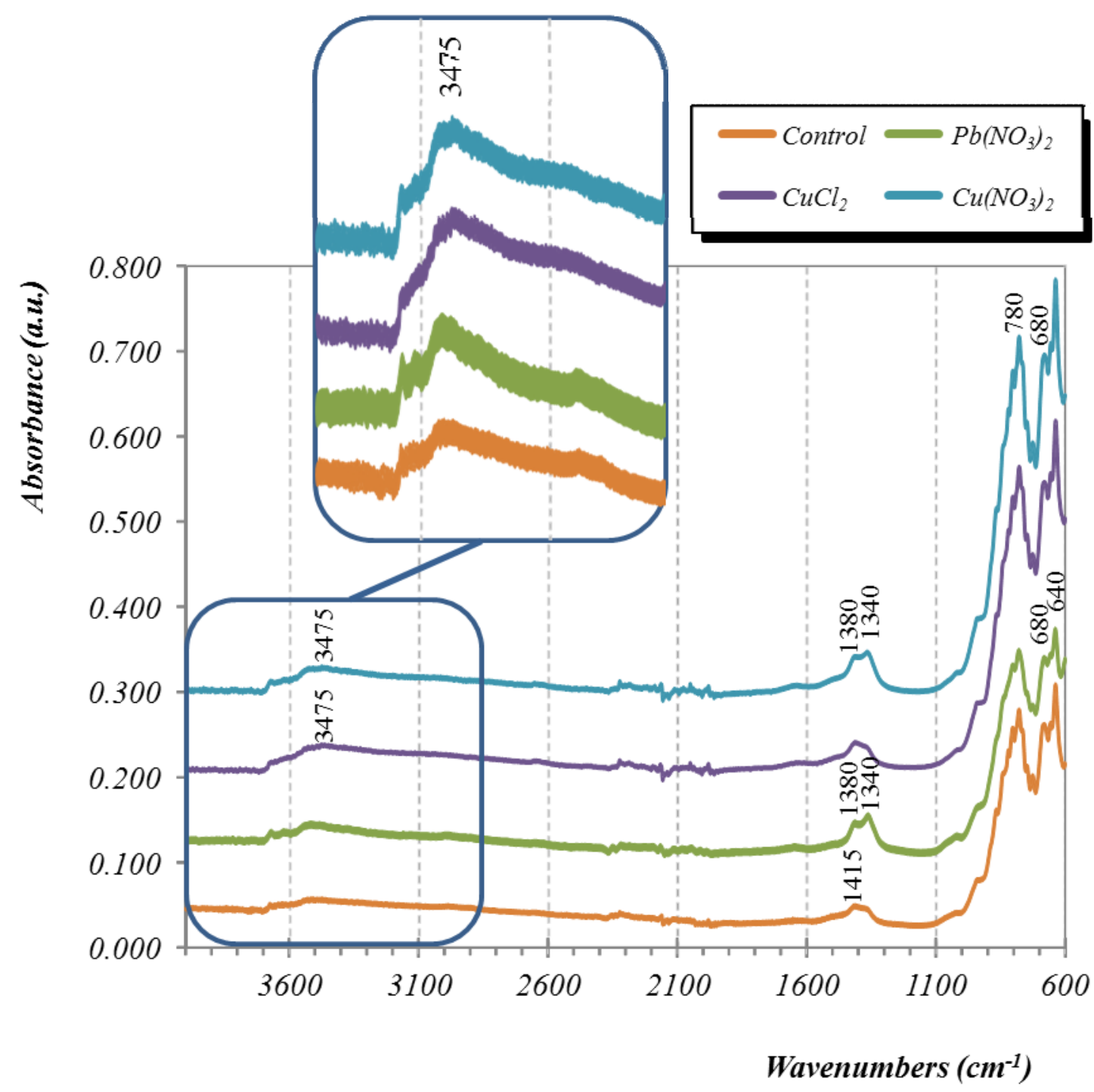

Figure 20. FTIR results of control and different samples treated with lead and copper salts after 48 hours. 